\title{
Experimental evidence for decompression melting of metasomatized mantle beneath Colima Graben, Mexico
}

\author{
Eduardo Becerra-Torres ${ }^{1} \cdot$ Elena Melekhova ${ }^{1} \cdot$ Jon D. Blundy ${ }^{1,2} \cdot$ Richard A. Brooker $^{1}$
}

Received: 6 January 2020 / Accepted: 19 September 2020 / Published online: 10 October 2020

(c) The Author(s) 2020

\begin{abstract}
Primitive subduction zone magmas provide information about the composition and thermal structure of the underlying mantle wedge. In the Colima Graben, Mexico, primitive lavas erupted from cinder cones range from high magnesium calc-alkaline basalts to high-K trachybasalts. This chemical diversity suggests that the sub-arc mantle wedge from which they derive is heterogeneous. To explore the conditions of magma generation in the wedge beneath Colima we used an inverse experimental approach to constrain multiple saturation points on the liquidus surface of a primitive high-K basanite (COM-1). Equilibrium piston-cylinder experiments were carried out between 1.0 and $2.4 \mathrm{GPa}$ under hydrous (1.8-3.8 wt $\left.\% \mathrm{H}_{2} \mathrm{O}\right)$ and oxidizing $\left(\mathrm{fO}_{2}=-0.5\right.$ to $4.3 \log$ units relative to $\mathrm{NNO}$ ) conditions. $\mathrm{COM}-1+3.8 \mathrm{wt} \% \mathrm{H}_{2} \mathrm{O}$ is shown to be multiply-saturated with a phlogopite-bearing spinel pyroxenite assemblage $(\mathrm{cpx}+\mathrm{opx}+\mathrm{phl}+\mathrm{sp})$ close to its liquidus at 1.9-2.4 GPa and $1300{ }^{\circ} \mathrm{C}$. Experimental mapping of the liquidus surface reveals a multiple saturation point (MSP) where a lherzolitic phase assemblage of ol $+\mathrm{cpx}+\mathrm{opx}+\mathrm{sp}+\mathrm{phl}$ coexist. The topology of the MSP indicates a peritectic of the form $\mathrm{cpx}+\mathrm{opx}+\mathrm{phl}+\mathrm{sp}=$ liquid + ol. Four bracketing experiments define the MSP of COM- 1 as $1300 \pm 10{ }^{\circ} \mathrm{C}, 1.7 \pm 0.1 \mathrm{GPa}$, $\Delta \mathrm{NNO}=3.4 \pm 0.5 \mathrm{log}$ units, for melt containing 3.6 $\pm 0.4 \mathrm{wt} \% \mathrm{H}_{2} \mathrm{O}$. The MSP olivine is too forsterite-rich $\left(\mathrm{Fo}_{92-94}\right)$ to be in equilibrium with mantle lherzolite, but matches phenocryst core compositions in the natural basanite. Thus, experimental results indicate that COM-1 was produced by incongruent melting of an olivine-free, phlogopite-pyroxenite source that itself is the result of metasomatism of mantle wedge by slab-derived fluids. These conditions provide a valuable constraint on the thermal structure and chemical composition of the mantle wedge beneath Colima.
\end{abstract}

Keywords Phlogopite peridotite $\cdot$ Mantle heterogeneity $\cdot$ High-potassium basalt $\cdot$ Colima graben $\cdot$ Multiple saturation . Incongruent melting

\section{Introduction}

Arc magmatism begins with the generation of primary magmas in the hot part of the mantle wedge between the subducted slab and the sub-arc crust. It is widely accepted that

Communicated by Timothy L. Grove.

Electronic supplementary material The online version of this article (https://doi.org/10.1007/s00410-020-01740-x) contains supplementary material, which is available to authorized users.

Eduardo Becerra-Torres

eduardo.becerratorres@bristol.ac.uk

1 School of Earth Sciences, University of Bristol, Wills Memorial Building, Bristol BS8 1RJ, UK

2 Department of Earth Sciences, University of Oxford, South Parks Road, Oxford OX1 3AN, UK most, but not all, primary arc magmas are basaltic (Gaetani and Grove 2003) and that fluids derived from the subducting slab play a key role in arc magmatism. Slab-derived fluids supply $\mathrm{H}_{2} \mathrm{O}$ and other components, notably silica and alkalis, that both depress the peridotite solidus and act as a metasomatic agent capable of generating non-lherzolite ultramafic lithologies, such as pyroxenite or wherlite (e.g., Bouihol et al. 2009). Beyond this simple petrological framework, we still know surprisingly little about the temperature at which melting occurs in the wedge, the depth at which mantle wedge-derived melts segregate from their source, the style and degree of mantle melting, and even the composition and mineralogy of the source lithology.

The simplest scenario, and one widely adopted in models of arc magmatism, is that mantle lherzolite undergoes batch melting at the maximum temperature encountered in the wedge in response to the addition of fluid from the slab 
(e.g., Katz et al. 2003; Rüpke et al. 2004). Thus, melting becomes simply a function of the local temperature and the mass fraction of $\mathrm{H}_{2} \mathrm{O}$ added. However, this very simplified view does not take into consideration the chemical diversity of erupted primary magmas nor the potential reaction of peridotite with ascending slab-derived fluids to produce fertile, metasomatic lithologies that deviate from lherzolite mineralogy. Given the petrological complexity of subduction zones it is unlikely that peridotite melting occurs simply by the addition of $\mathrm{H}_{2} \mathrm{O}$ to fertile mantle lherzolite. On the basis of trace element geochemistry (Schiano et al. 2004; Foley et al. 2013) and reaction experiments between slab fluids and peridotite (Prouteau et al. 2001; Grant et al. 2016; Grove and Till 2019), it is likely that the mantle wedge is heterogeneous and comprises lithologies other than lherzolite alone. It is also possible that mantle wedge lherzolite itself has experienced depletion due to prior melt extraction, producing relatively refractory lithologies, such as a harzburgite (e.g., Grove et al. 2003) that can also react with slab-derived metasomatic fluids. The problem is further exacerbated by the fact that we do not know the thermal structure of the mantle wedge. Existing thermal models (e.g., Syracuse et al. 2010) tend to place the hottest part of the wedge at pressures around $3 \mathrm{GPa}$ where garnet is a stable residual phase in lherzolite. However, relatively few primary arc basalts carry an unequivocal residual garnet trace element signature from the mantle wedge (Thomas et al. 2002), moreover, the origin of this signature is still controversial and frequently ascribed to metasomatic events (Hastie et al. 2011).

The potential diversity of mantle wedge lithologies may account for the wide range of primary arc magmas. High-potassium, nepheline-normative $\mathrm{MgO}$-rich basalts (sometimes referred to as 'basanites') are a minor variety of primary magma that occurs in many arcs including Izu-Bonin-Mariana, Kamchatka, Sierra Nevada, Sunda, and western Mexico (e.g., Ishizuka et al. 2010; Portnyagin et al. 2007; Vollmer and Norry 1983; Gertisser et al. 2012; Luhr and Carmichael 1981). These rocks have distinctive chemical characteristics and unusual phenocryst mineralogies (e.g., phlogopite, feldspathoid) indicating a different petrogenesis to more common primitive calc-alkaline and tholeiitic arc basalts. The Colima Volcanic Complex (CVC), in the Western Trans-Mexican Volcanic Belt, has produced a remarkable variety of hydrous, primitive magmas, including high-K and calc-alkaline varieties, erupted from monogenetic cones (Gómez-Tuena et al. 2018). These features make CVC an ideal location for exploring the origin of highpotassium, primary arc basalts.

\section{Tectonic and geochemical overview of Colima Volcanic Complex}

The Trans-Mexican Volcanic Belt (TMVB) is a continental arc generated by eastward subduction of the Rivera and Cocos plates below the North American plate (Fig. 1a). The TMVB is emplaced into variably thick continental crust and the CVC itself lies above the boundary between the young and steeply dipping $\left(\sim 65^{\circ}\right)$ Rivera plate and the shallower dipping Cocos plate. As a result, the western TMVB tectonic framework is dominated by a three-rift system related to the rollback of the Rivera plate to its current deep position at $10 \mathrm{Ma}$ (Manea et al. 2013) to produce the N-W trending Tepic-Zacoalco Rift, the E-W Chapala Rift and the N-S trending Colima Graben (Fig. 1a).

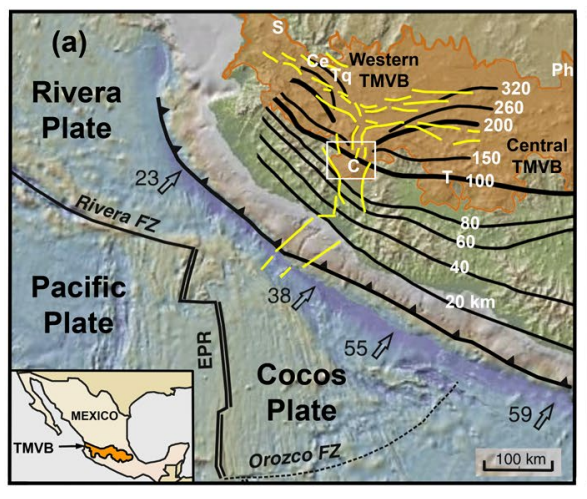

Fig. 1 a Location map for the western Trans-Mexican Volcanic Belt (TMVB); the square marks the position of the Colima Volcanic Complex (CVC) within the Colima Graben as detailed in (b). In a the convergence direction and rate (in $\mathrm{mm} / \mathrm{yr}$ ) of the Rivera and Cocos plates are indicated; contours represent the depth to the subducting slab. Yellow lines represent fault systems that define the NE-SW oriented Colima Graben and the E-W Tepic and Chapala rifts. Major stratovolcanoes are identified from east to west: Sangangüey (S),

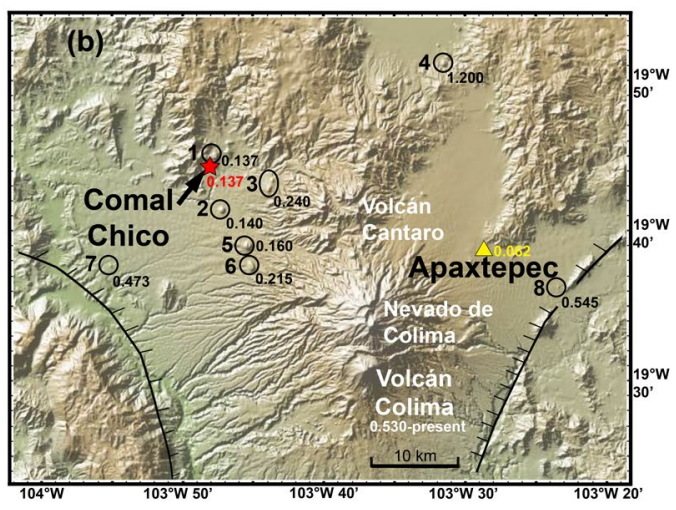

Ceboruco (Ce), Colima (C), Tequila (Tq), Tancítaro (T), Palo Huerfano $(\mathrm{Ph})$. In $\mathbf{b}$ the location of the ten monogenetic cones of the CVC are shown along with their Ar-Ar ages (Ma): Comal Chico (red star), Apaxtepec (yellow triangle), and Comal Grande (1), Telcampana (2), Carpintero Norte y Sur (3), Usmajac (4), La Erita (5), San Isidro (6), Cuauthemoc (7), Tezontal (8). Maps, ages and structures modified from Carmichael et al. (2006), and Ferrari et al. (2012). EPR East Pacific Rise, $F Z$ fracture zone 
The CVC is a very complex sector of the TMVB in that it lies within the Colima Graben, the focus of extension for the last $\sim 5 \mathrm{Ma}$, and has experienced significant faulting. Gradual divergence of the Rivera and Cocos plates has led to the development of a slab gap below the northern sector of the Colima Graben (Manea et al. 2013). The CVC lies approximately $150 \mathrm{~km}$ from the Middle American Trench, and is defined by three prominent stratovolcanoes; Volcán Fuego de Colima (currently active), Volcán Nevado de Colima, and Volcán Cántaro, surrounded by a field of ten monogenetic cones (Fig. 1b, Carmichael et al. 2006).

The monogenetic CVC cones have erupted lavas and scoria that are compositionally distinct from both medium-K andesites of the three stratovolcanoes and the medium- $\mathrm{K}$ basalts and andesites of monogenetic cones that dominate the Michoacan-Guanajuato Volcanic Field to the east (Hasenak and Carmichael 1987). Eight of the CVC cones are nepheline-normative, shoshonitic trachybasalts previously referred to as basanites (Luhr and Carmichael 1981), one is primitive high- $\mathrm{Al}$ calc-alkaline basalt, and one is calcalkaline basaltic andesite. The most voluminous potassic lavas comprise approximately $1.3 \mathrm{~km}^{3}$ of magma erupted between 0.240 and $0.260 \mathrm{Ma}$, a time window that coincides with a hiatus between eruptive activity at Nevado de Colima following the Atenquique explosive event $0.38-0.26 \mathrm{Ma}$ (Robin et al. 1987), and the onset of activity at Volcan de Colima's predecesor 'Paleofuego' (Carmichael et al. 2006). The two calc-alkaline cinder cones are significantly older (0.545 and 1.22 Ma; Carmichael et al. 2006) and produced much smaller volumes of magma $\left(0.0003 \mathrm{~km}^{3}\right)$ consistent with the beginning of the Colima Rift and the first volcanic manifestations at Volcán El Cántaro (Allan and Carmichael 1984).

\section{Experimental rationale}

In this study we employ an inverse experimental approach to investigate the origin of a $0.137 \mathrm{Ma}$ CVC basanite from Comal Chico (Table 1, Fig. 1b) by exploring its near-liquidus mineralogy at P-T- $\mathrm{H}_{2} \mathrm{O}-\mathrm{fO}_{2}$ conditions consistent with an upper mantle origin (e.g., Falloon et al. 1999; Pichavant et al. 2002; Melekhova et al. 2015). This approach is very sensitive to the $\mathrm{P}-\mathrm{T}-\mathrm{H}_{2} \mathrm{O}-\mathrm{fO}_{2}$ space that is explored, potentially yielding precise source conditions.

The concept of a multiple saturation point (MSP) is described in detail by Wyllie (1984) but warrants some further consideration. In a low-variance, synthetic system, such
Table 1 Anhydrous compositions of natural and experimental materials

\begin{tabular}{|c|c|c|c|c|}
\hline \multirow[t]{2}{*}{ Sample } & \multicolumn{2}{|l|}{ Natural Sample } & \multicolumn{2}{|c|}{$\begin{array}{l}\text { Synthetic experimental } \\
\text { material }\end{array}$} \\
\hline & COM-1 & Apaxtepec & COM-1_1 & COM-1_28 \\
\hline $\mathrm{SiO}_{2}$ & 48.82 & 49.82 & 49.53 & 50.37 \\
\hline $\mathrm{TiO}_{2}$ & 1.31 & 1.66 & 1.40 & 1.30 \\
\hline $\mathrm{Al}_{2} \mathrm{O}_{3}$ & 12.08 & 13.51 & 12.28 & 12.02 \\
\hline FeOT & 8.73 & 9.18 & 7.45 & 8.00 \\
\hline $\mathrm{MnO}$ & 0.13 & 0.14 & 0.18 & 0.14 \\
\hline $\mathrm{MgO}$ & 12.69 & 9.35 & 12.88 & 12.70 \\
\hline $\mathrm{CaO}$ & 8.60 & 9.25 & 8.74 & 8.48 \\
\hline $\mathrm{Na}_{2} \mathrm{O}$ & 2.47 & 2.43 & 2.69 & 2.21 \\
\hline $\mathrm{K}_{2} \mathrm{O}$ & 4.02 & 3.67 & 3.80 & 3.70 \\
\hline $\mathrm{P}_{2} \mathrm{O}_{5}$ & 1.14 & 0.98 & 1.05 & 1.09 \\
\hline $\mathrm{H}_{2} \mathrm{O}$ & $0.9-3.7^{\mathrm{a}}$ & $0.4-4.4^{\mathrm{a}}$ & $1.8^{\mathrm{e}}$ & $3.8^{\mathrm{e}}$ \\
\hline $\mathrm{Cr}(\mathrm{ppm})$ & 696.6 & 463.6 & 807.5 & 779.7 \\
\hline $\mathrm{Mg} \#$ & 72.15 & 64.47 & 75.50 & 73.89 \\
\hline$\Delta \mathrm{NNO}^{\mathrm{b}}$ & $3.4 \pm 0.3$ & $2.9 \pm 0.3$ & n.d & n.d \\
\hline Temperature $(\mathrm{ol}-\mathrm{liq})^{\mathrm{c}}$ & $1288-1300 \pm 29$ & $1190-1200 \pm 29$ & & \\
\hline Temperature (phl-liq) $)^{\mathrm{d}}$ & $1060-1090 \pm 50$ & n.d & & \\
\hline Olivine core Fo $(\%)$ & $90-92$ & $87-88$ & & \\
\hline \multicolumn{5}{|l|}{ n.d. not determined } \\
\hline \multicolumn{5}{|c|}{ a range of $\mathrm{H}_{2} \mathrm{O}$ in wt\% from melt inclusions, Vigoroux et al. (2008) } \\
\hline \multicolumn{5}{|c|}{${ }^{b}$ Ballhaus et al. (1991) oxybarometer } \\
\hline \multicolumn{5}{|c|}{${ }^{\mathrm{c}}$ Putirka (2008) olivine-melt thermometer at $1 \mathrm{GPa}\left({ }^{\circ} \mathrm{C}\right)$} \\
\hline \multicolumn{5}{|c|}{${ }^{\mathrm{d}}$ Righter and Carmichael (1996) phlogopite-melt thermometer $\left({ }^{\circ} \mathrm{C}\right)$} \\
\hline e initial $\mathrm{H}_{2} \mathrm{O}$ added to th & ting material & & & \\
\hline
\end{tabular}


as the four component $\mathrm{CaO}-\mathrm{MgO}-\mathrm{Al}_{2} \mathrm{O}_{3}-\mathrm{SiO}_{2}$, multiple saturation occurs at a unique $\mathrm{P}-\mathrm{T}$ point where five solid phases, e.g., ol $+\mathrm{cpx}+\mathrm{opx}+\mathrm{gt}+\mathrm{sp}$, coexist on the liquidus, i.e. the thermodynamic variance of the system is zero. Multiple saturation in natural systems does not equate to invariance or isobaric invariance because of the larger number of components (Asimow and Longhi 2004). Instead further constraints are required to reduce the variance. These include temperature, $\mathrm{fO}_{2}$ and $\mathrm{H}_{2} \mathrm{O}$ content of the melt, inferred for example from the petrology of the rock selected as the experimental starting material, and close compositional matches of experimental mineral phases to those found in the starting material and/or expected in the source region.

MSP determinations are further complicated by the nature of the melting reaction. For peritectic melting, which is often the case for mantle rocks, the reactant and product solid phases straddle the multiple saturation point (MSP), whereas in the eutectic case all reactant phases coexist with the melt at the MSP. In peritectic melting, MSP determination cannot be used to identify unequivocally the mineralogy of the source; the product mineral phase(s) may or may not be present at the onset of melting. No such ambiguity exists for eutectic melting. This distinction is of relevance to our experimental results when assessing the nature of the source lithology. Despite these complexities, the inverse approach has the potential to provide robust $\mathrm{P}-\mathrm{T}-\mathrm{H}_{2} \mathrm{O}-\mathrm{fO}_{2}$ estimates for the point of last equilibrium of a magma with its source prior to ascent (Asimow and Longhi 2004).

In this study we consider an experiment to be multiply saturated if it crystallises at least four mineral phases very close to its liquidus ( $>95 \%$ melt). $\mathrm{H}_{2} \mathrm{O}$ constraints are provided by melt inclusions in near-liquidus phenocrysts, while $\mathrm{fO}_{2}$ can be estimated from oxybarometry (olivine-Cr-spinel; Ballhaus et al. 1991) or the $\mathrm{Fe}^{3+} / \mathrm{Fe}^{2+}$ ratio of the natural rock (Kress and Carmichael 1991). The temperature constraint is provided by the eruption temperature, as estimated from geothermometry because primary magmas must have ascended rapidly from their source region with negligible subsequent differentiation. Thus, the source temperature differs only from the eruption temperature by an adiabatic cooling factor, which is of the order of a few ${ }^{\circ} \mathrm{C}$ per $\mathrm{km}$ (McKenzie and Bickle 1988).

Even with these additional constraints locating a MSP can be an arduous task if 'scatter gun' experiments are used to search blindly across P-T- $\mathrm{H}_{2} \mathrm{O}-f \mathrm{O}_{2}$ space. To help constrain this problem, we used pMELTS (Ghiorso et al. 2002) to narrow the $\mathrm{P}-\mathrm{T}-\mathrm{H}_{2} \mathrm{O}-f \mathrm{O}_{2}$ space over which the starting composition is likely to be multiply-saturated as a guide to experimental conditions (Supplementary Fig. 1S). (A comparison of the experimental results to those of pMELTS modelling is presented in Sect. 5.3). We then chose the optimum combination of intensive and extensive parameters, within the range allowable by the natural starting material.
This resulted in a more oxidized and $\mathrm{H}_{2} \mathrm{O}$-rich system compared to previous studies on similar starting compositions (e.g., Lloyd et al. 1985; Tatsumi and Koyaguchi 1989; Funk and Luth 2012; see Table 3S). By meticulous mapping of the liquidus surface phase assemblage within this parameter range we identify plausible source mineralogies and melting reactions (Green and Ringwood 1967; Edgar et al. 1992; Falloon et al. 1999). The P-T conditions of multiple saturation provide the conditions at which a magma segregated from its source, rather than the point at which melting began (Assimow and Longhi 2004). This distinction is important in the case of polybaric melting.

\section{Methods}

\section{Starting composition}

The most primitive magmas (11.0-13.8 wt $\% \mathrm{MgO})$ in the $\mathrm{CVC}$ are also some of the most $\mathrm{K}_{2} \mathrm{O}$-rich (3.2-4.2 wt\%) (Fig. 2). Comal Chico monogenetic cone has previously been recognised as a classic example of the high-K, primitive magmatism of the area (Luhr and Carmichael 1981; Vigoroux et al. 2008; Gómez-Tuena et al. 2011). Samples collected from Comal Chico and Apaxtepec (donated by M Mangler) were analysed by XRF at the University of Leicester (Table 1), and phases analysed in thin sections by EMPA (Table 2S). The Comal Chico sample used as the basis for our starting composition (COM-1, Table 1) is a low crystallinity lava with $12.7 \mathrm{wt} \% \mathrm{MgO}$ (Mg\# 75.3), $4.0 \mathrm{wt} \% \mathrm{~K}_{2} \mathrm{O}$, $354 \mathrm{ppm} \mathrm{Ni}$ and $687 \mathrm{ppm} \mathrm{Cr}$ with $20 \mathrm{vol} \%$ phenocrysts of olivine $\left(\mathrm{Fo}_{88-93}\right)$, clinopyroxene (Mg\#: $\left.72-85\right)$, plagioclase, phlogopite and oxides. The groundmass contains the same mineral phases with the addition of analcime. The estimated eruption temperature of COM-1 is between $\sim 1280 \pm 20{ }^{\circ} \mathrm{C}$ (olivine-liquid geothermometer of Putirka 2008) and $1060-1190^{\circ} \mathrm{C}$ (phlogopite-liquid Ti-thermometer, Righter and Carmichael 1996). The calculated $\mathrm{fO}_{2}$ of COM-1 is $\mathrm{NNO}+3.5 \pm 0.3 \log$ units according to Ballhaus et al. (1991) spinel-olivine oxybarometer, and $\mathrm{NNO}+2.7 \log$ units based on its $\mathrm{Fe}^{3+} / \mathrm{Fe}_{\mathrm{T}}$ ratio of 0.49 (Carmichael et al. 2006). Melt inclusions have not been analyzed for Comal Chico, however, the mean $\mathrm{H}_{2} \mathrm{O}$ measured in 21 olivine-hosted $\left(\mathrm{Fo}_{88-91}\right)$ melt inclusion from the compositionally-similar Apaxtepec (Table 1) basanites of the CVC (Fig. 1b) is $2.5 \pm 1.3 \mathrm{wt} \%$ (Vigoroux et al. 2008), the least degassed, highest $\mathrm{CO}_{2}$ $\left(\geq 0.3 \mathrm{wt} \%\right.$ ) melt inclusions have 3.7 to $6.2 \mathrm{wt} \% \mathrm{H}_{2} \mathrm{O}$.

Two initial starting materials with different $\mathrm{H}_{2} \mathrm{O}$ contents were prepared from a mixture of oxides $\left(\mathrm{SiO}_{2}, \mathrm{MgO}, \mathrm{MnO}\right.$, $\left.\mathrm{Al}_{2} \mathrm{O}_{3}, \mathrm{TiO}_{2}, \mathrm{Fe}_{2} \mathrm{O}_{3}\right)$, carbonates $\left(\mathrm{CaCO}_{3}, \mathrm{Na}_{2} \mathrm{CO}_{3}, \mathrm{~K}_{2} \mathrm{CO}_{3}\right)$, $\mathrm{Al}(\mathrm{OH})_{3}$ and calcium phosphate. $\mathrm{Al}_{2} \mathrm{O}_{3}, \mathrm{SiO}_{2}, \mathrm{TiO}_{2}, \mathrm{MgO}$, $\mathrm{MnO}$ were dried at $1000^{\circ} \mathrm{C}$ for $24 \mathrm{~h}$ to remove moisture, while the carbonates and $\mathrm{Ca}_{3}\left(\mathrm{PO}_{4}\right)_{2}$ were dried at $200{ }^{\circ} \mathrm{C}$ 
Fig. 2 Major element plots showing CVC cinder cones (white diamonds) and Volcán de Colima stratovolcano products (grey circles) taken from Georoc database. COM-1 composition used as experimental starting material is shown with a red star; by definition melts from the liquidus MSP have this composition. The two yellow triangles show the sub-liquidus MSPs representing reactions $2 \mathrm{a}$ (COM-1_36 at $9.9 \% \mathrm{MgO}$ ) and 2b (COM-1_48 at $7.8 \% \mathrm{MgO})$. Grey diamonds show the compositional spread of magmas from Apaxtepec cinder cone
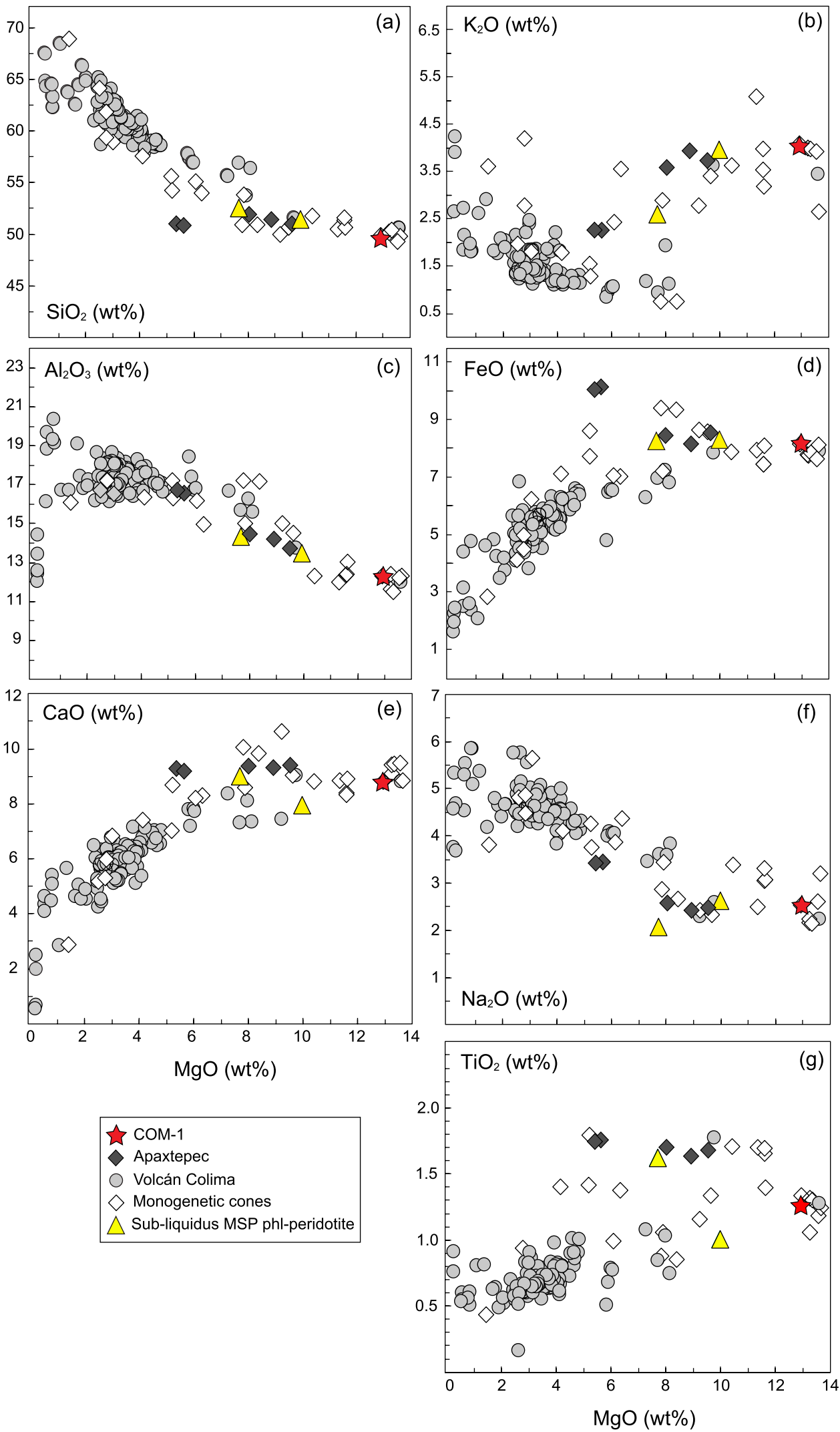
in an oven overnight. Two separate batches of $\mathrm{Al}_{2} \mathrm{O}_{3}, \mathrm{SiO}_{2}$, $\mathrm{TiO}_{2}, \mathrm{MgO}, \mathrm{MnO}, \mathrm{Ca}_{3}\left(\mathrm{PO}_{4}\right)_{2}$ and carbonates were weighed, mixed and homogenised by grinding in an agate mortar. Both mixtures were decarbonated in a Pt crucible for $4 \mathrm{~h}$ in a box furnace, ramping-up temperature from 600 to 1000 ${ }^{\circ} \mathrm{C}$. $\mathrm{Fe}_{2} \mathrm{O}_{3}$ was then added to both decarbonated powders and rehomogenised. An aliquot of each powder was pressed into a pellet and separately equilibrated for $2 \mathrm{~h}$ at $1000{ }^{\circ} \mathrm{C}$ in a gas-mixing furnace at $\sim \mathrm{NNO}+2$ to reduce some of the $\mathrm{Fe}^{3+}$ to $\mathrm{Fe}^{2+}$. As a final stage $\mathrm{Al}(\mathrm{OH})_{3}$ was added as a water source to each aliquot to achieve two starting materials with 3.8 and $1.8 \mathrm{wt} \% \mathrm{H}_{2} \mathrm{O}$ (Table 1). Both starting materials were also doped with a total of $\sim 1890 \mathrm{ppm}$ of selected trace elements ( $\mathrm{Nb}, \mathrm{Ta}, \mathrm{Zr}, \mathrm{Hf}, \mathrm{Ni}, \mathrm{Cr}, \mathrm{V}, \mathrm{Sc}, \mathrm{Y}, \mathrm{Sr}, \mathrm{Cr}$ ), in the form of ICP-standard solutions for a trace element partitioning study that will be published elsewhere. No sulphur or chlorine was added to the starting materials, so the effects of these two components on phase relations is not considered here.

\section{Experimental technique}

Liquidus temperatures and phase relations can be very sensitive not only to pressure (P), temperature (T) and $\mathrm{H}_{2} \mathrm{O}$ content but also to $f \mathrm{O}_{2}$. It is difficult to control $f \mathrm{O}_{2}$ in pistoncylinder runs due to hydrogen and carbon permeability of the capsule and cell material, which mediates $\mathrm{fO}_{2}$ through redox reactions involving $\mathrm{H}_{2} \mathrm{O}, \mathrm{CO}_{2}, \mathrm{FeO}$ and $\mathrm{Fe}_{2} \mathrm{O}_{3}$. To minimise this effect, experiments with a low water content adopted a double-capsule design; but for the high-water experiments we used a single capsule to enhance the quench rate sufficiently to produce homogeneous run product glass. Between 8 and $10 \mathrm{mg}$ of starting material were loaded into annealed $\mathrm{Au}_{80} \mathrm{Pd}_{90}$ (o.d. $2 \mathrm{~mm}$ ) capsules; for double-capsule experiments these capsules were inserted into an $\mathrm{Au}_{80} \mathrm{Pd}_{20}$ outer capsule (o.d. $3 \mathrm{~mm}$ ) filled with 30-40 $\mathrm{mg}$ of the same starting material. The outer capsule acts as a barrier/sink to delay the ingress or egress of $\mathrm{H}$ and $\mathrm{C}$ (Brooker et al. 1998; Hall et al. 2004; Kägi et al. 2005; Melekhova et al. 2015). With this precaution, $f \mathrm{O}_{2}$ is strongly influenced by the loaded $\mathrm{Fe}^{3+} / \mathrm{Fe}_{\mathrm{T}}$ ratio in the starting material powders. Three experiments were also performed with a powdered $\mathrm{MnO}-\mathrm{Mn}_{3} \mathrm{O}_{4}$ buffer $+\mathrm{H}_{2} \mathrm{O}$ in the outer capsule. This buffer lies approximately $3.6 \mathrm{log}$ units above NNO (O'Neill and Pownceby 1993).

A total of thirty experiments were carried out in a halfinch $(12.7 \mathrm{~mm})$, end-loaded piston-cylinder apparatus at the University of Bristol. Pressures ranged from 1.0 to 2.4 GPa and temperatures from 1000 to $1360{ }^{\circ} \mathrm{C}$. The NaCl-Pyrex$\mathrm{MgO}$ assemblies require a friction correction of $-3 \%$, based on calibrations employing the quartz $=$ coesite transition at $3.1 \mathrm{GPa}$ and $1000{ }^{\circ} \mathrm{C}$ (McDade et al. 2002). Temperatures were monitored with $\mathrm{W}_{95} \operatorname{Re}_{5} / \mathrm{W}_{75} \operatorname{Re}_{25}$ thermocouples with an estimated accuracy of $\pm 5^{\circ} \mathrm{C}$; no correction of pressure on thermocouple e.m.f. was applied. The expected thermal gradient is $\sim 10{ }^{\circ} \mathrm{C}$ per $5 \mathrm{~mm}$ (Kägi et al. 2005). The single capsule experiments are $\sim 3 \mathrm{~mm}$ long; double-capsule experiments are $\sim 6 \mathrm{~mm}$ long. To minimise carbon infiltration from the graphite furnace, a Pyrex sleeve was placed around the capsule and Pyrex powder was used to fill any void space (Matjuschkin et al 2015). Run durations were 6-24 h depending on temperature and $\mathrm{H}_{2} \mathrm{O}$ content; a few super-liquidus experiments were run for only $1 \mathrm{~h}$ (Table 2 ).

\section{Analytical methods}

Major element compositions of experimental phases were analysed by electron microprobe analysis (EPMA) on Cameca SX100 and JEOL JXA-8600, Field Emission Gun (FEG) microprobes at the University of Bristol using standard calibration techniques with oxide and silicates. For the anhydrous silicate phases, the EPMA set up was: $20 \mathrm{kV}$ accelerating voltage, $10 \mathrm{nA}$ bean current and $1 \mu \mathrm{m}$ beam diameter. To minimise alkali loss during the analysis of hydrous glasses we used a defocused beam $(10 \mu \mathrm{m})$, lower beam current $(4 \mathrm{nA})$ and reduced count times on Na. However, experiments with abundant quench material and/ or high crystallinity can only be measured with a smaller spot increasing the reported loss of $\mathrm{Na}_{2} \mathrm{O}$ (Table 2). Due to their small size $(\leq 10 \mu \mathrm{m})$ phlogopite crystals were analysed with the FEG instrument using $9 \mathrm{kV}$ accelerating voltage, 5 $\mathrm{nA}$ beam current and $0.5 \mu \mathrm{m}$ beam diameter. Modal proportions of phases were determined by least-squares regression (Table 2). The maximum number of suitably large grains of each mineral were analysed. As most runs are near-liquidus, the total number of analysable grains was often limited, and in some runs only one analysable grain could be found.

Volatile contents of experimental glasses were analysed by secondary ion mass spectrometry (SIMS) at the NERC ion microprobe facility, University of Edinburgh, using a Cameca IMS 7f-Geo instrument with a nominal $10 \mathrm{kV}$ primary beam of ${ }^{16} \mathrm{O}^{-}$ions and $5 \mathrm{nA}$ beam current, resulting in a spot size at the sample surface of $\sim 15 \mu \mathrm{m}$ (following Melekhova et al. 2015). $\mathrm{H}_{2} \mathrm{O}$ and $\mathrm{CO}_{2}$ were calibrated against synthetic basaltic glass standards (Shiskina et al. 2010) containing $\leq 3.5 \mathrm{wt} \% \mathrm{H}_{2} \mathrm{O}$ and $\leq 2000 \mathrm{ppm} \mathrm{CO}_{2}$. Working curves of ${ }^{1} \mathrm{H} /{ }^{30} \mathrm{Si}$ vs $\mathrm{H}_{2} \mathrm{O}$ and ${ }^{12} \mathrm{C} /{ }^{30} \mathrm{Si} \times \mathrm{SiO}_{2}$ vs. $\mathrm{CO}_{2}$ gave straight lines with $R^{2} \geq 0.99$ (Fig. 2S).

\section{Approach to equilibrium}

Several factors can affect equilibrium in experimental run products: gain or loss of volatiles via diffusion through the capsule walls: temperature gradients, persistence of unreacted starting material, or insufficient run duration. In the majority of these experiments there is no significant $\mathrm{H}_{2} \mathrm{O}$ 


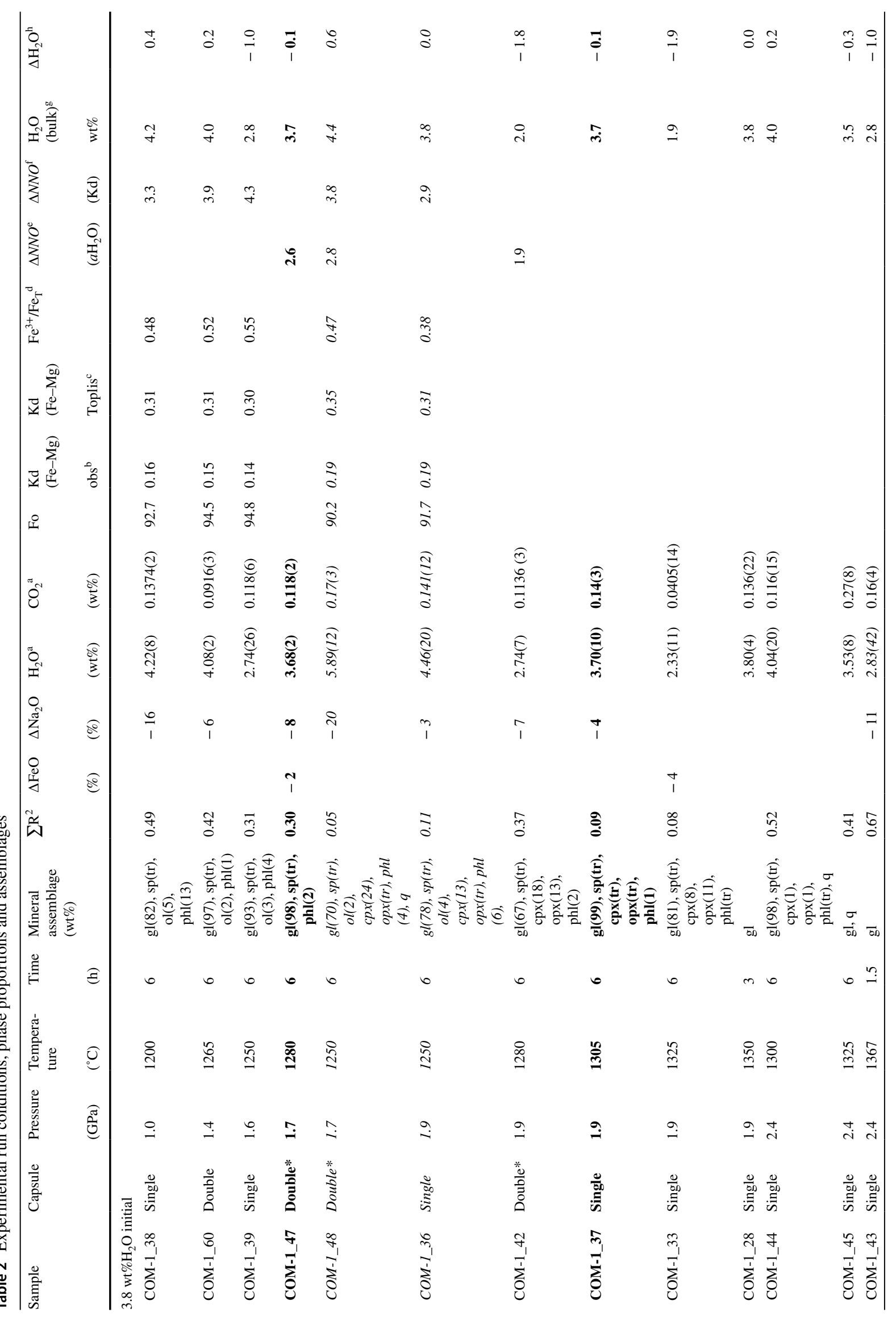




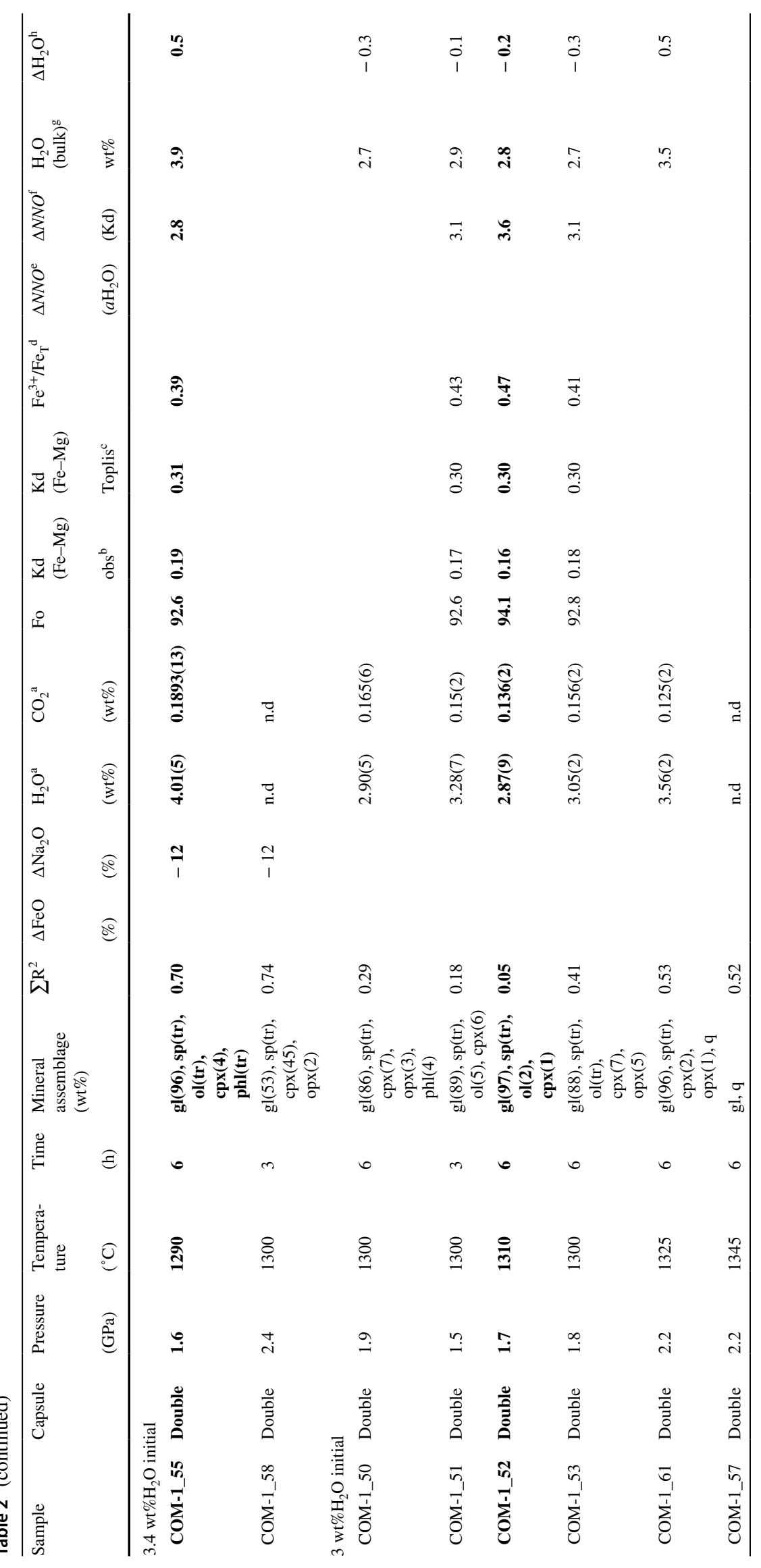




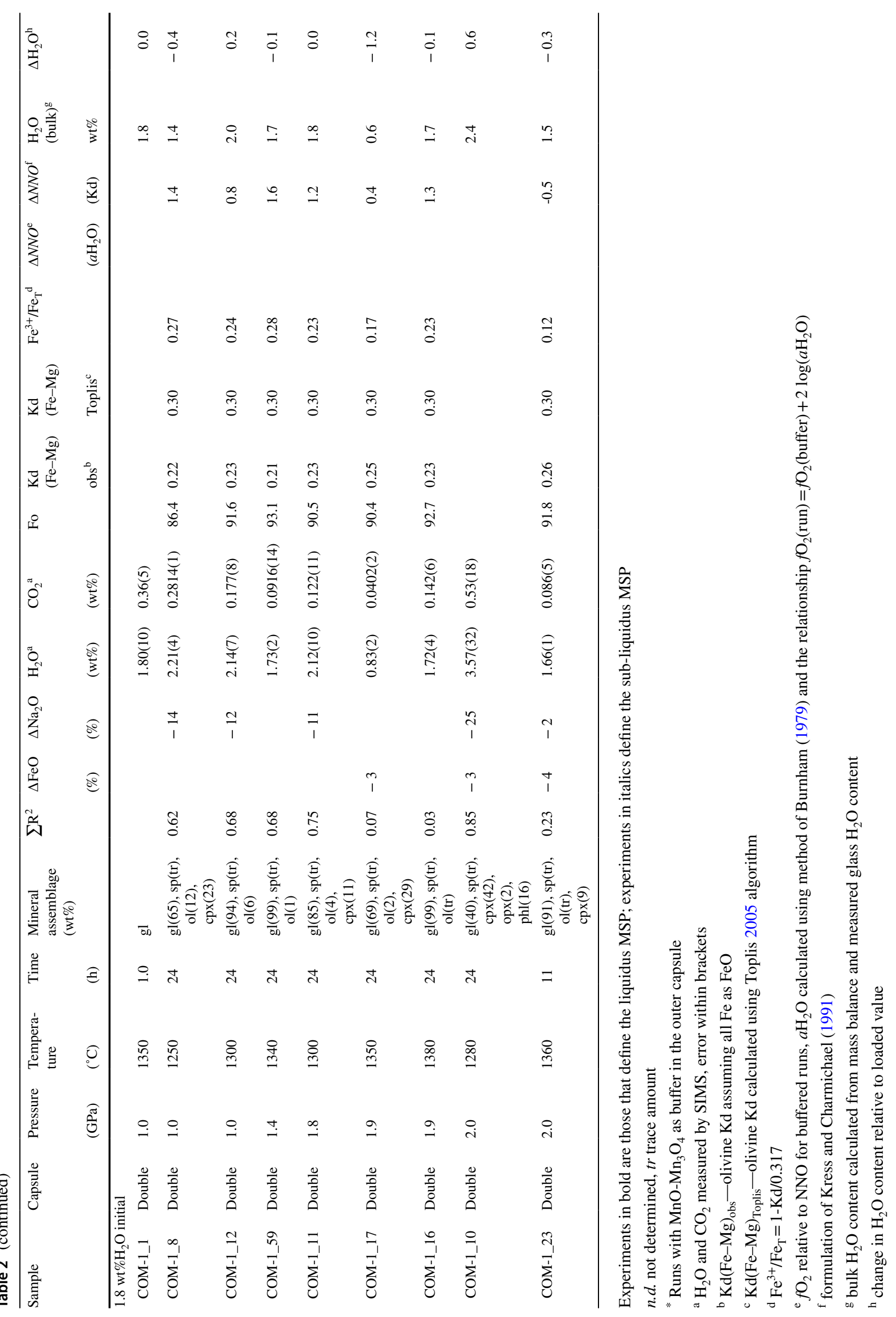


gain or loss (see below). Run product glasses are homogeneous and crystals have euhedral to subhedral morphology with no (or minor) zoning (Fig. 3). Mass balance calculations show that the bulk composition of the starting material was successfully recreated from the run product phases (Table 2). Previous work on similar compositions has shown that run duration of 6-24 $\mathrm{h}$ is sufficient to reach equilibrium (Edgar et al. 1992; Elkins-Tanton and Grove 2003). The relatively short runs of the great majority of our experiments and the use of AuPd capsule material at high $\mathrm{fO}_{2}$ are designed to minimise Fe loss. No unreacted material was found in any experimental run product. Quench crystals are unavoidable in experiments with primitive hydrous melts and are present in most of our experimental run products. However, only in two (COM-1_48 and COM-1_44) do they exceed 5 vol\% (15 and $7 \%$, respectively).

\section{Results}

Experimental run conditions, phase assemblages and phase proportions, along with any calculated relative $\mathrm{Fe}$ and $\mathrm{Na}$ loss, are presented in Table 2. All runs are fluid undersaturated. Melt and mineral chemistry for experimental runs products are reported in Table 1S (Supplementary Material).

\section{Volatile contents}

SIMS analyses of $\mathrm{H}_{2} \mathrm{O}$ and $\mathrm{CO}_{2}$ in run product glasses are listed in Table 2. These values can deviate from the loaded $\mathrm{H}_{2} \mathrm{O}$ contents as a result of hydrogen and carbon diffusion into (or out of) the capsule and/or adsorption of $\mathrm{H}_{2} \mathrm{O}$ and $\mathrm{CO}_{2}$ onto powdered starting materials prior to loading the capsules. In the case of $\mathrm{H}_{2} \mathrm{O}$, it is possible to calculate the bulk $\mathrm{H}_{2} \mathrm{O}$ content using the measured value in the glass and its mass fraction, as determined by mass balance; where phlogopite is also a run product, we estimated its contribution to the $\mathrm{H}_{2} \mathrm{O}$ budget assuming it has a content of $6 \mathrm{wt} \%$. The calculated bulk $\mathrm{H}_{2} \mathrm{O}$ contents are reported in Table 2, along with the $\mathrm{H}_{2} \mathrm{O}$ loss or gain relative to the loaded value. Of the 28 experiments where glass $\mathrm{H}_{2} \mathrm{O}$ was measured by SIMS, in 23 experiments $\mathrm{H}_{2} \mathrm{O}$ change is less than $\pm 0.6 \mathrm{wt} \%$ (i.e., within the fully propagated error on phases proportions and $\mathrm{H}_{2} \mathrm{O}$ analysis), including those used to define the liquidus MSP. In five experiments $\mathrm{H}_{2} \mathrm{O}$ loss or gain was between 1.0 and $1.9 \mathrm{wt} \%$. There is no correlation between the magnitude of $\mathrm{H}_{2} \mathrm{O}$ loss or gain and run duration, nor between the estimated oxidation state of the run (see below), suggesting that adsorption of moisture onto starting materials, rather than hydrogen diffusion, played a significant role.

Measured glass $\mathrm{CO}_{2}$ contents are all nonzero-400-5300 ppm. Assuming that the starting material was fully decarbonated, this indicates that carbon infiltration also occurred from the graphite furnace (Brooker et al. 1998). Formation of $\mathrm{CO}_{2}$ in this way is consistent with that described by Stamper et al. (2014), who suggest that this is a widespread feature of piston-cylinder experiments. Again, there is no correlation with run duration, although there is a slight tendency for the experiments showing the greatest $\mathrm{CO}_{2}$ gain to show the greatest $\mathrm{H}_{2} \mathrm{O}$ gain (e.g. COM-1_23), which again could be suggestive of adsorption onto starting material.

\section{Oxygen fugacity}

Natural cinder cone lavas from CVC, including Comal Chico, are relatively oxidised, a fact that undoubtedly influences their phase relations. Three runs (Table 2) were buffered for $f \mathrm{O}_{2}$ using $\mathrm{MnO}+\mathrm{Mn}_{3} \mathrm{O}_{4}+\mathrm{H}_{2} \mathrm{O}$ in the outer capsule. In each case all three buffer phases were present at the end of the run, indicating that the buffer capacity was not exhausted. Deploying $\mathrm{MnO}+\mathrm{Mn}_{3} \mathrm{O}_{4}+\mathrm{H}_{2} \mathrm{O}$ controls $f \mathrm{H}_{2}$ via $\mathrm{H}$ diffusion through the capsule walls. Where the sample is $\mathrm{H}_{2} \mathrm{O}$-saturated the $f \mathrm{O}_{2}$ of the sample corresponds to that of the buffer, i.e. $\mathrm{NNO}+3.6$. Where the sample is water-undersaturated, the sample $f \mathrm{O}_{2} \operatorname{lies} 2 \log \left(a \mathrm{H}_{2} \mathrm{O}\right)$ below the buffer, where $a \mathrm{H}_{2} \mathrm{O}$ is the water activity. We have estimated $a \mathrm{H}_{2} \mathrm{O}$ for the three buffered runs using the measured glass $\mathrm{H}_{2} \mathrm{O}$ contents and the method of Burnham (1979), although we recognise that our run conditions are well outside the calibration range of his method. The calculated $a \mathrm{H}_{2} \mathrm{O}$ is in the range 0.14 to 0.40 . The corresponding $f \mathrm{O}_{2}$ lies in the range $\mathrm{NNO}+1.9$ to $\mathrm{NNO}+2.8$ (Table 2) for these buffered runs.

For unbuffered runs, we attempted to create appropriate redox conditions by synthesising the two starting material powders at relatively high $f_{2}(\sim \mathrm{NNO}+2)$ prior to loading the capsules (see above). Using this method the exact ratio of $\mathrm{Fe}^{3+}$ to total $\mathrm{Fe}\left(\mathrm{Fe}^{3+} / \mathrm{Fe}_{\mathrm{T}}\right)$ in the powder is sensitive to the kinetics of the various solid-state redox reactions and the quench rate of the pressed pellet. Although our target $\mathrm{Fe}^{3+} / \mathrm{Fe}_{\mathrm{T}}$ was around 0.4 for the two mixtures there is no guarantee at the point of synthesis that it was the same in the starting materials with 3.8 and $1.8 \mathrm{wt} \% \mathrm{H}_{2} \mathrm{O}$. For this reason, we have attempted to estimate $f \mathrm{O}_{2}$ in the unbuffered runs by applying oxybarometry to the run products.

There is no spinel large enough for EMPA analysis in our run products, preventing the use of olivine-spinel oxybarometry to estimate run $\mathrm{fO}_{2}$. An alternative, and less precise, method is to use the deviation of olivine-melt $\mathrm{Fe}-\mathrm{Mg}$ exchange from the expected value as a means to estimate $\mathrm{Fe}^{3+} / \mathrm{Fe}^{2+}$, which can then be converted to $f \mathrm{O}_{2}$ using the algorithm of Kress and Carmichael (1991). This method has been successfully applied by Nandedkar et al (2014) who used a value of $K d_{\mathrm{Fe}-\mathrm{Mg}}=0.317$ based on Ulmer (1989) to determine $\mathrm{Fe}^{3+} / \mathrm{Fe}_{\mathrm{T}}$, then the expression of Kress and Carmichael (1991) to determine $\mathrm{fO}_{2}$ for the experimental melt 


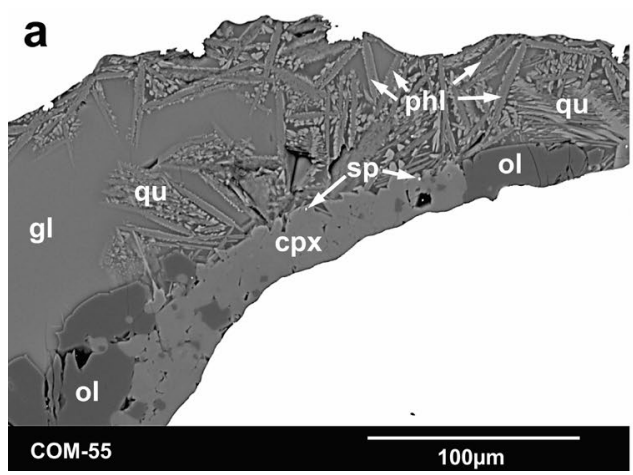

Fig. 3 Back-scattered electron photomicrographs of experimental run products. The larger patches of melt away from the equilibrium crystals have successfully quenched to a glass (gl), but the crystals themselves clearly act as a nucleation site for quench (qu) crystallization. a COM-1_55 (1.6 GPa, $\left.1290{ }^{\circ} \mathrm{C}\right)$ : clinopyroxene (cpx), olivine (ol), and phogopite (phl) occur as well-formed, generally unzoned crystals that are clearly distinguished from quench phases. b COM-

composition at run $\mathrm{P}$ and $\mathrm{T}$. Rather than use a fixed value for $K d_{\mathrm{Fe}-\mathrm{Mg}}$ we calculated instead $K d_{\mathrm{Fe}-\mathrm{Mg}}$ for each experimental glass and olivine composition using the method of Toplis (2005). For the sixteen olivine-bearing runs (Table 2), the resulting $\mathrm{Fe}^{3+} / \mathrm{Fe}_{\mathrm{T}}$ ratios are $0.46 \pm 0.06$ and $0.22 \pm 0.06$ for runs with 3-3.8 and $1.8 \mathrm{wt} \%$ of $\mathrm{H}_{2} \mathrm{O}$, respectively. These values are broadly consistent with the target $\mathrm{Fe}^{3+} / \mathrm{Fe}_{\mathrm{T}}$ ratio of the starting material, however, the lower $\mathrm{H}_{2} \mathrm{O}$ starting material is less oxidised than the one with higher $\mathrm{H}_{2} \mathrm{O}$. Calculated $\mathrm{fO}_{2}$ values are in the range of NNO-0.5 to $\mathrm{NNO}+1.6$ and $\mathrm{NNO}+2.8$ to $\mathrm{NNO}+4.3$ for runs with initial 1.8 and 3-3.8 wt $\% \mathrm{H}_{2} \mathrm{O}$, respectively. For the single run (COM-1_47) that is both olivine-bearing and $\mathrm{MnO}-\mathrm{Mn}_{3} \mathrm{O}_{4}$-buffered the two methods agree to within $\pm 0.55 \log$ units in $\mathrm{fO}_{2}$ (Table 2); we consider this to be at the limits of the accuracy of the two methods.

\section{Phase relations}

In Fig. 4 we present the near-liquidus $\mathrm{P}-\mathrm{T}$ phase relations for experiments with initial $\mathrm{H}_{2} \mathrm{O}$ of 1.8-3.8 wt\%. For both sets of experiments, the liquidus is relatively well-defined and is lower by about $60{ }^{\circ} \mathrm{C}$ for the wetter starting material, in excellent agreement with the expression of Médard and Grove (2008). With $1.8 \mathrm{wt} \%$ added $\mathrm{H}_{2} \mathrm{O}$, olivine and spinel are the liquidus assemblages (Fig. 4a). Clinopyroxene appears almost $100{ }^{\circ} \mathrm{C}$ below the liquidus at $1 \mathrm{GPa}$ and by slightly less at $2 \mathrm{GPa}$. In all near-liquidus experiments with 1.8 wt $\%$ initial $\mathrm{H}_{2} \mathrm{O}$, olivine compositions are $\mathrm{Fo}_{92-93}$ and clinopyroxenes have $\mathrm{Mg} \#_{86-89}$. Figure $4 \mathrm{a}$ shows clearly that COM-1 with initial $\mathrm{H}_{2} \mathrm{O}$ of $1.8 \mathrm{wt} \%$ cannot be multiplysaturated at the liquidus with any mantle peridotite lithology.

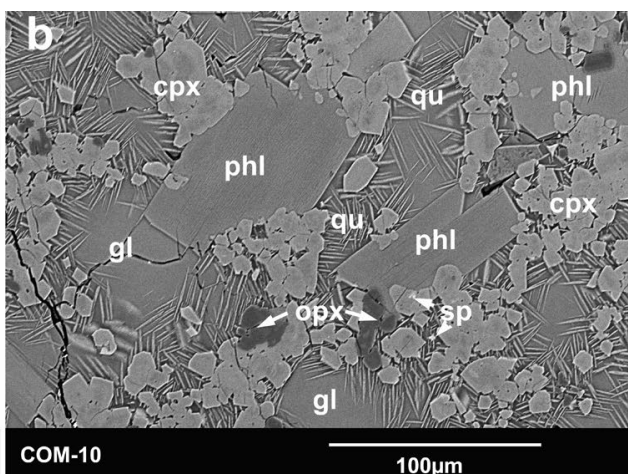

1_10 (2.0 GPa, $\left.1280{ }^{\circ} \mathrm{C}\right)$ : equilibrium orthopyroxene (opx), cpx and phl are distinguishable by form and greyscale tone from their needlelike quench counterparts. Bright region in a is the capsule. Consistent composition and mass balance calculations demonstrate that the isolated glass areas analysed have not been affected by quench crystallization

Experiments with 3.8 wt $\%$ of $\mathrm{H}_{2} \mathrm{O}$ yield a phase diagram with a slightly different topology (Fig. 4b). Phlogopite + spinel + clinopyroxene + orthopyroxene coexist on the liquidus at 1.9 and $2.4 \mathrm{GPa}$. A phlogopite-peridotite assemblage (phlogopite + spinel + clinopyroxene + orthopyroxene + olivine) occurs $50{ }^{\circ} \mathrm{C}$ below the liquidus at 1.7 and $1.9 \mathrm{GPa}$. Near-liquidus olivine is $\left(\mathrm{Fo}_{90-93}\right)$; orthopyroxene is $\mathrm{En}_{86-89}$; clinopyroxene has $\mathrm{Mg \#}_{78-87}$ and phlogopite $\mathrm{Mg \#}_{71-85}$. Pyroxenes are not stable at lower pressures. Clinopyroxenes differ from those of the natural COM-1 phenocrysts, whereas the olivines match well with phenocryst core compositions (Table $2 \mathrm{~S}$ ). As expected, increasing the initial $\mathrm{H}_{2} \mathrm{O}$ promotes orthopyroxene and phlogopite stability at the expense of the olivine, and increases the likelihood of finding a lherzolitic MSP at the liquidus.

\section{Liquidus surface of hydrous, high- $\mathrm{K}_{2} \mathrm{O}$ primitive magmas}

To better define the liquidus surface of COM-1 and locate the MSP where phlogopite + spinel + clinopyroxene + orthopyroxene + olivine coexist, we carried out a further series of experiments with 3.0-3.4 wt\% loaded $\mathrm{H}_{2} \mathrm{O}$ (Table 2). The starting compositions for these experiments were made by mixing the 3.8 and $1.8 \mathrm{wt} \% \mathrm{H}_{2} \mathrm{O}$ powders in appropriate proportions.

Ten experiments, from the new $\left(3.0\right.$ and $\left.3.4 \mathrm{wt} \% \mathrm{H}_{2} \mathrm{O}\right)$ and original (1.8 and $\left.3.8 \mathrm{wt} \% \mathrm{H}_{2} \mathrm{O}\right)$ series have melt fractions $\geq 0.95$ and can be used to construct the liquidus surface (Fig. 5). Experimental runs with lower melt fractions contain more evolved melts and, therefore, cannot 
Fig. 4 Experimentally-determined phase diagrams for COM- 1 basanite with a 1.8 and b $3.8 \mathrm{wt} \%$ added $\mathrm{H}_{2} \mathrm{O}$. Phase assemblages are shown using pentagons. Note the presence in $\mathbf{b}$ of two experiments with 5 solid phases in equilibrium with melt lying approximately $50{ }^{\circ} \mathrm{C}$ below the liquidus of COM-1. These are referred to as 'sub-liquidus MSPs'; their melt composition matches magmas from the Apaxtepec cone, as denoted by yellow triangles in Fig. 2. In $\mathbf{b}$ the liquidus MSP of COM-1 (see Fig. 5) lies at approximately $1.9 \mathrm{GPa}$ and $1300{ }^{\circ} \mathrm{C}$
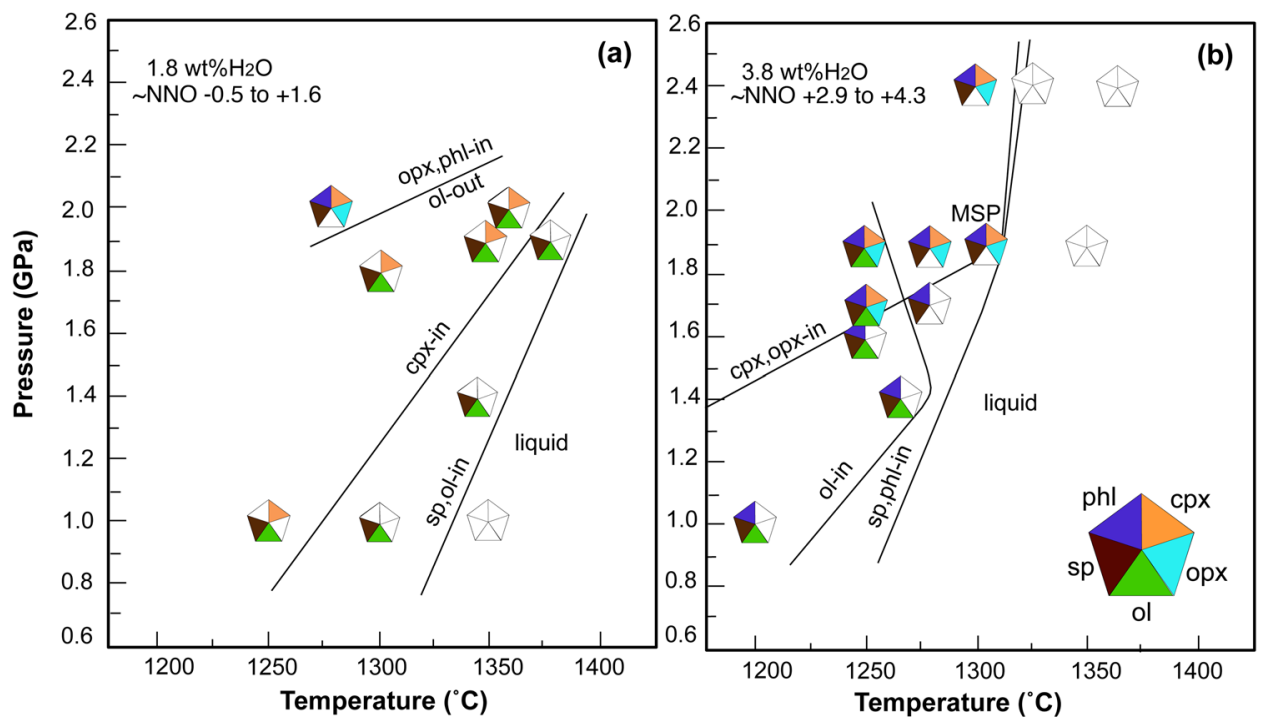

be interpreted in terms of the mantle source of COM1. Four experiments (shown in bold in Table 2) bracket precisely an MSP of phlogopite + spinel + clinopyroxene + orthopyroxene + olivine at $1300 \pm 10{ }^{\circ} \mathrm{C}, 1.7 \pm 0.1$ $\mathrm{GPa}, \mathrm{fO}_{2}=3.4 \pm 0.5 \mathrm{log}$ units above NNO, and a melt $\mathrm{H}_{2} \mathrm{O}$ content of $3.6 \pm 0.4 \mathrm{wt} \%$. At higher temperatures and lower pressures on the liquidus surface (Fig. 5) orthopyroxene and phlogopite disappear from the liquidus, to be replaced by olivine $\left(\mathrm{Fo}_{92-94}\right)$. Clinopyroxene disappears at a lower temperature. Spinel is ubiquitous in the vicinity of the MSP. The presence of olivine \pm clinopyroxene on one side of the MSP and orthopyroxene + phlogopite \pm clinopyroxene on the other indicates a peritectic melting reaction of the form: $\mathrm{cpx}+\mathrm{opx}+\mathrm{phl}+\mathrm{sp}=$ liquid + ol. Thus COM-1 is consistent with melting of phlogopite pyroxenite that produces olivine as a peritectic product. Importantly, the high Fo content of product olivines argues against the melting of a phlogopite-lherzolite source, as they are too magnesian for typical mantle lherzolite $\left(\mathrm{Fo}_{90-91}\right)$.

\section{Additional multiple saturation points}

As noted above, two low-temperature experiments from the original series with $3.8 \mathrm{wt} \% \mathrm{H}_{2} \mathrm{O}$ (COM-1_48 and 36 ), containing only $70-78 \%$ melt, have attained multiple saturation with phlogopite + spinel + clinopyroxene + orthopyroxene + olivine, albeit at conditions well below the liquidus of COM-1, i.e. $1250{ }^{\circ} \mathrm{C}$ at 1.7 and 1.9 GPa (show in italics in Table 2 and Fig. 4). These MSPs do not lie on the liquidus surface of COM-1, however, they do help to extend the $\mathrm{cpx}+\mathrm{opx}+\mathrm{phl}+\mathrm{sp}=$ liquid $+\mathrm{ol}$ peritectic to lower temperatures. The melts in COM-1_48 and COM-1_36 are plotted in Fig. 6. As expected, they

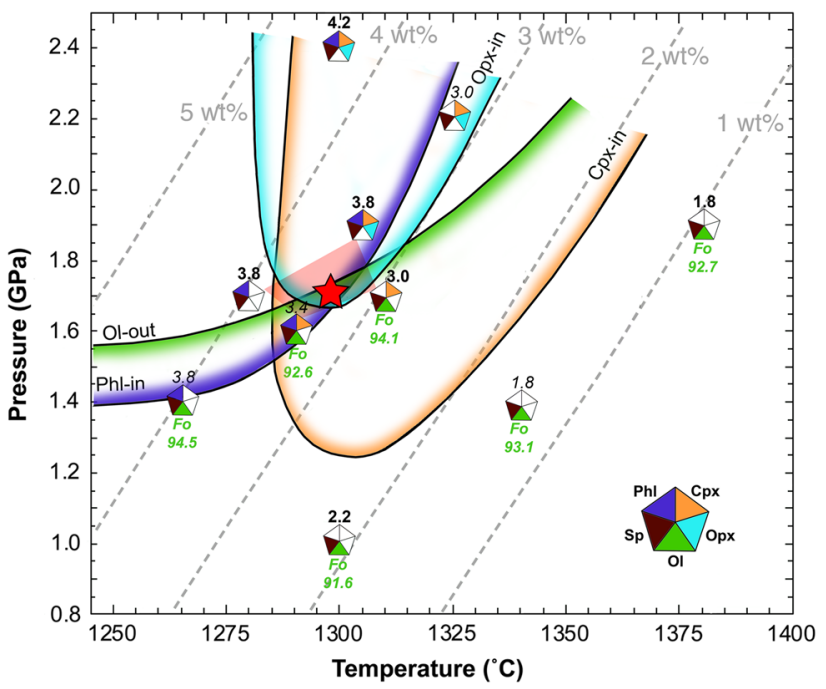

Fig. 5 Liquidus surface diagram for bulk composition COM-1 used to define the liquidus MSP. Only experiments containing $\geq 95 \%$ glass are plotted. Pentagons as in Fig. 4. The olivine composition (mol\% Fo in green) and melt $\mathrm{H}_{2} \mathrm{O}$ content are marked next to each experiment; measured (SIMS) values shown in bold font, values estimated by the mass balance in regular font. Liquidus contours (dashed grey) are labelled with the corresponding $\mathrm{H}_{2} \mathrm{O}$ content of the melt. The pink shaded quadrilateral containing the red star is defined by the 4 surrounding experiments listed in bold in Table 2. These define the peritectic liquidus multiple saturation point (MSP) of COM-1. Note that the experiments with $\leq 2.2 \mathrm{wt} \% \mathrm{H}_{2} \mathrm{O}$ were performed at lower $f \mathrm{O}_{2}$ than those at higher $\mathrm{H}_{2} \mathrm{O}$, and are indicative only of the low- $\mathrm{H}_{2} \mathrm{O}$ extrapolation of the liquidus surface. All MSP-defining experiments were performed at $\mathrm{NNO}+3.4 \pm 0.5$ (Table 2 )

differ significantly from COM-1, but provide a very good match to some other CVC cinder cone magmas, notably Apaxtepec (Fig. 1 and Table 1). The olivines in these 
Fig. 6 Major element composition of CVC cinder cones (white diamonds) compared to multiply-saturated melts from this study and experiments (pastel ellipses) on similar starting compositions (Mallik et al. 2015; Sekine and Wyllie 1983; Condamine and Medard 2014; Tatsumi and Koyaguchi 1989); ellipse dimensions represent the reported uncertainty in the composition. Note that the multiply-saturated experimental melts cover the entire range of CVC cinder cone compositions
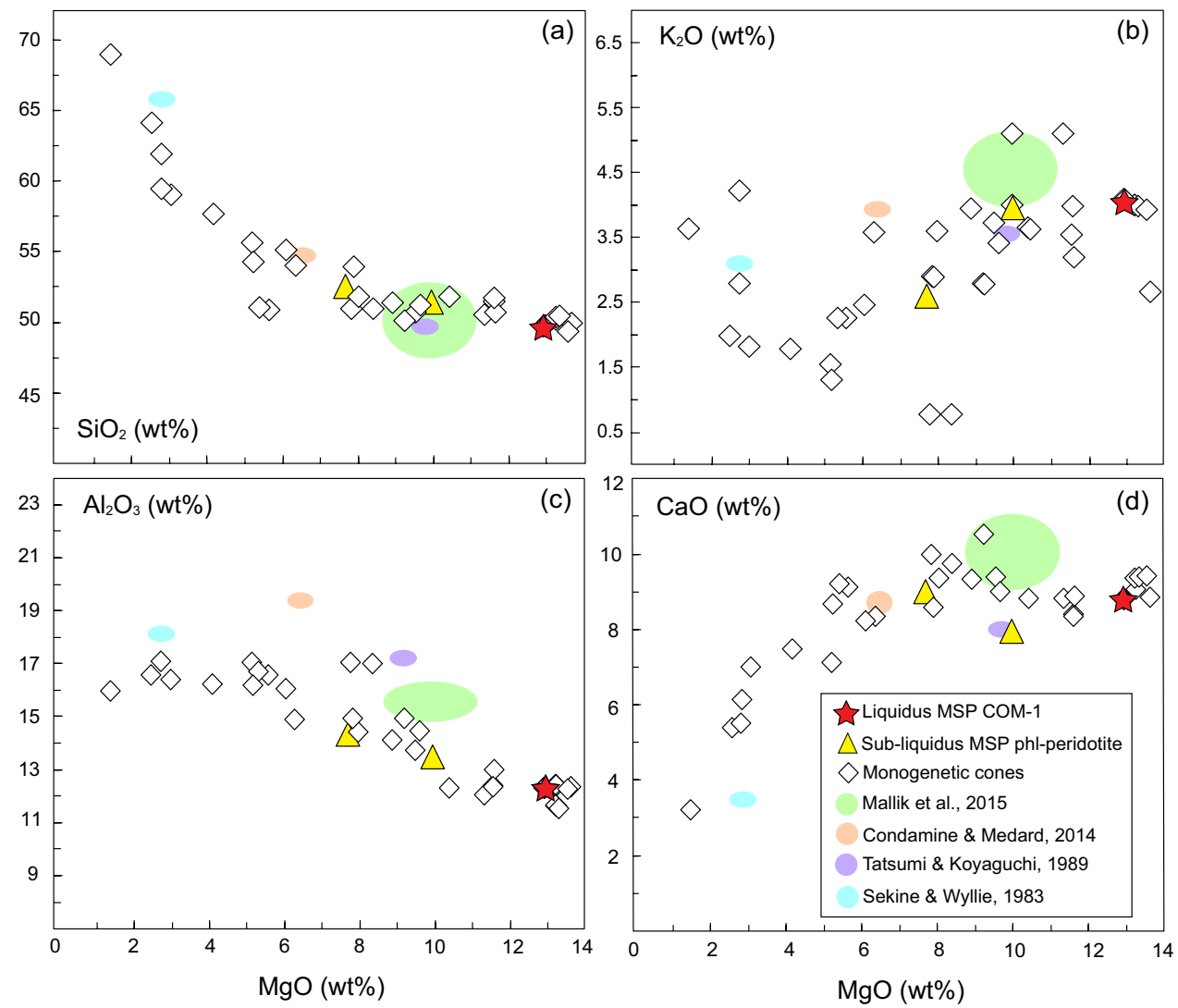

two multiply-saturated runs are less forsteritic $\left(\mathrm{Fo}_{90-92}\right.$, Fig. 7) than at the COM-1 liquidus MSP and more in keeping with mantle lherzolite, even though the melting reaction remains peritectic. Melt $\mathrm{H}_{2} \mathrm{O}$ contents are correspondingly higher (4.6-6.1 wt $\%) ; \mathrm{fO}_{2}$ is $\sim \mathrm{NNO}+3.5 \pm 0.5$ similar to that of the liquidus MSP.

\section{Discussion}

\section{Comparison to other studies}

The location of the liquidus MSP of COM-1 lies close to that determined experimentally in the anhydrous synthetic system diopside-kalsilite-forsterite-silica-fluorine by Melzer and Foley (2000). At 1.8 GPa their invariant point olivine + fluor-phlogopite + clinopyroxene + orthopyroxene + liquid lies at $1370 \pm 20{ }^{\circ} \mathrm{C}$. Because that system is quaternary, the coexistence of five phases is isobarically invariant. For comparison, the equivalent invariant point at atmospheric pressure lies at $1125 \pm 25^{\circ} \mathrm{C}$. The $70 \pm 20{ }^{\circ} \mathrm{C}$ offset between our determined MSP and that of Melzer and Foley (2000) undoubtedly reflects the absence of $F$ and the additional influence of $\mathrm{Fe}_{2} \mathrm{O}_{3}$ and $\mathrm{H}_{2} \mathrm{O}$. The reaction at the synthetic, isobarically-invariant point is also peritectic. Melzer and Foley (2000) emphasise the importance of this reaction boundary in controlling the chemistry of melts derived from phlogopite-bearing ultramafic rocks.

In the hydrous synthetic system $\mathrm{K}_{2} \mathrm{O}-\mathrm{MgO}-\mathrm{CaO}-\mathrm{Al}_{2} \mathrm{O}_{3}-\mathrm{SiO}_{2}-\mathrm{H}_{2} \mathrm{O}$, Modreski and Boettcher (1973) identify a peritectic melting reaction $p h l+c p x+o p x=$ liquid $+s p+o l$. (Note that spinel appears as a product phase.) This is a six-component system, so the equilibrium is divariant. For starting compositions along the phlogopite + enstatite + diopside plane, melting by this reaction begins at $1125{ }^{\circ} \mathrm{C}$ at $1 \mathrm{GPa}, 1225^{\circ} \mathrm{C}$ at $2 \mathrm{GPa}$ and $1325^{\circ} \mathrm{C}$ at $2.7 \mathrm{GPa}$, providing a reasonable estimate of the dehydration-melting solidus of phlogopite pyroxenites within the mantle. In the presence of $\mathrm{FeO}$ and $\mathrm{Fe}_{2} \mathrm{O}_{3}$, which can enter both reactant and product mineral phases, we anticipate that the solidus will be offset to slightly lower temperatures. More importantly, the positive $(\mathrm{dT} / \mathrm{dP}>0)$ slope of the solidus in $\mathrm{P}-\mathrm{T}$ space means that natural phlogopite pyroxenites will undergo decompression melting if they ascend adiabatically through the mantle.

There have been several determinations of near-solidus melting reactions in natural phlogopite-bearing ultramafic systems. Conceiçao and Green (2004) and Mengel and Green (1986) determined the solidus of metasomatised (amphibole + phlogopite-bearing) peridotite at pressures to 3.5 GPa. Their solidus, which involves dehydration melting of both phlogopite and amphibole, lies at $1135 \pm 15^{\circ} \mathrm{C}$ 
at $1.5 \mathrm{GPa}$, rising to $1170 \pm 10{ }^{\circ} \mathrm{C}$ at $2.5 \mathrm{GPa}$ when garnet appears on the solidus. Phlogopite (and amphibole) is consumed only $20{ }^{\circ} \mathrm{C}$ above the solidus, largely because of the low $\mathrm{K}_{2} \mathrm{O}$ and $\mathrm{H}_{2} \mathrm{O}$ contents of the starting materials (only $1.5 \mathrm{wt} \%$ phlogopite). Between the solidus and phlogopiteout curves at both 1.5 and $2.5 \mathrm{GPa}$ the phase assemblage is ol + cpx + opx + phlog + sp. This solidus is $\sim 40{ }^{\circ} \mathrm{C}$ lower than that determined by Modreski and Boettcher (1973) consistent with the modest influence of $\mathrm{FeO}$ and $\mathrm{Fe}_{2} \mathrm{O}_{3}$ in the natural systems. However, we cannot rule out that the presence of sub-solidus amphibole plays a role in reducing the onset of melting. It should also be noted that the starting composition used by Conceiçao and Green (2004) is considerably more fertile than the source inferred for COM-1, e.g. olivines in their starting materials have $\mathrm{Fo}_{90}$ compositions, compared to $\mathrm{Fo}_{92-94}$ at our liquidus MSP. This fertility difference will also impact the solidus temperature, as noted for the decrease in MSP temperature in our experiments from 1300 to $1250{ }^{\circ} \mathrm{C}$ as olivines change from $\mathrm{Fo}_{92-94}$ to $\mathrm{Fo}_{90-92}$.

Melting temperatures and melting reactions for phlogopite peridotite were determined by Condamine and Médard (2014) at $1 \mathrm{GPa}$. Their solidus lies at $1225^{\circ} \mathrm{C}$ at $1 \mathrm{GPa}$, similar to Modreski and Boettcher's (1973) determinations. Condamine et al. (2016) further determine the phlogopitegarnet-peridotite solidus at $3 \mathrm{GPa}$ at $1330{ }^{\circ} \mathrm{C}$, confirming the positive slope of the solidus of Modreski and Boettcher (1973).

\section{Comparison to MELTS modelling}

To explore the thermodynamic feasibility of a multiple-saturation point, and as a prelude to the experiments (see above) pMELTS (Ghiorso et al. 2002) simulations were run with COM-1 composition over a 1-3 GPa pressure range. All sets of $\mathrm{P}-\mathrm{T}-\mathrm{H}_{2} \mathrm{O}$ values were run with the starting composition ferric/ferrous set appropriate to $\mathrm{NNO}+1.8$ (Kress and Carmichael 1991; Borisov et al. 2015). Calculations were made without fixing the oxygen fugacity giving rise to a range of output $f \mathrm{O}_{2}$ of $\sim \mathrm{NNO}+3$ to +3.4 . Figure $1 \mathrm{~S}$ shows phases diagrams with $2 \mathrm{wt} \%$ and $4 \mathrm{wt} \% \mathrm{H}_{2} \mathrm{O}$. Biotite, rather than end-member phlogopite, is the only hydrous mineral that pMELTS produces. Both phase diagrams at 1.6-2.0 GPa show that the phase-in curves approach sufficiently closely to suggest a feasible multiple saturation point, albeit with
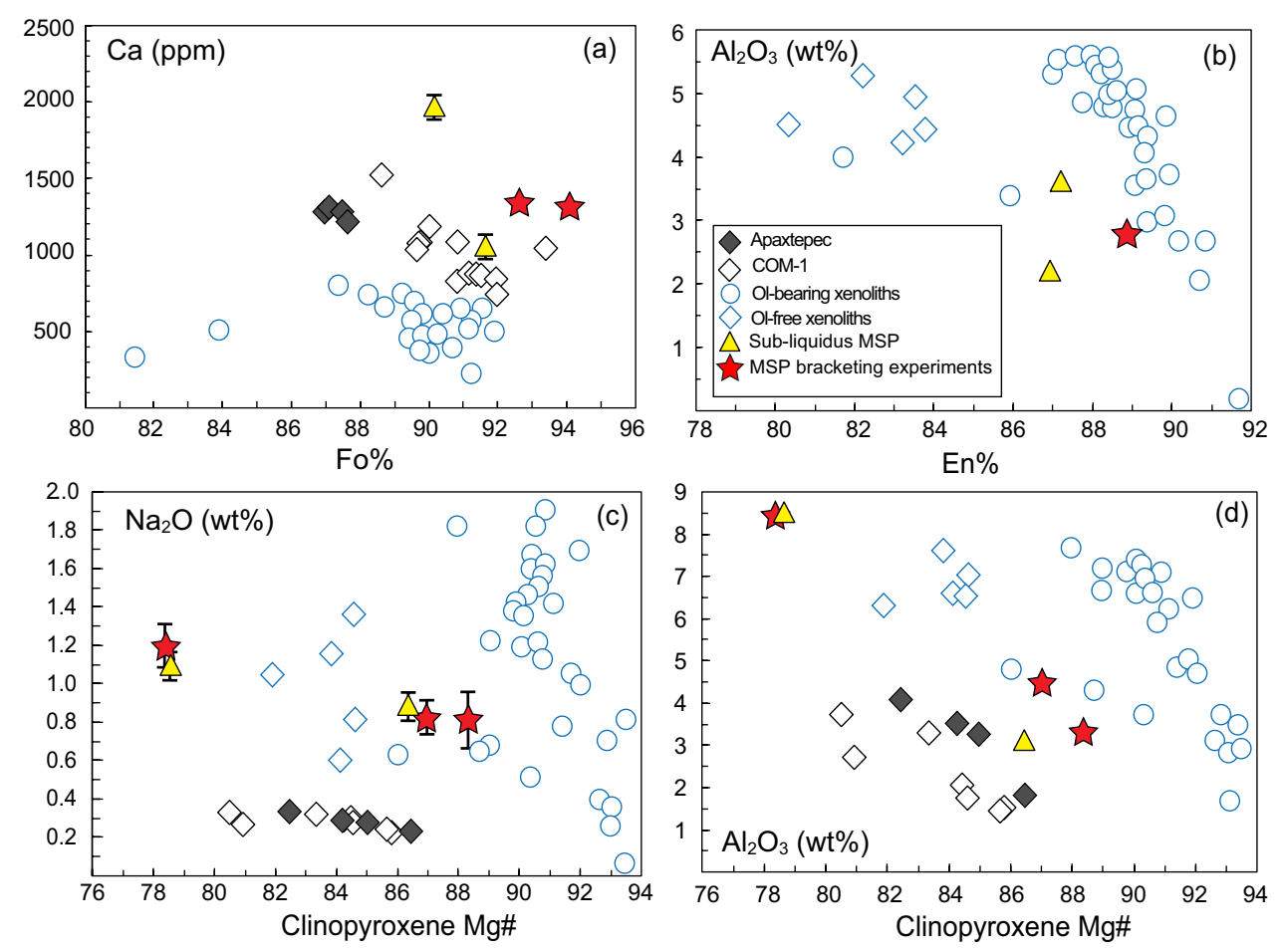

Fig. 7 Major and minor elements in a olivine, b orthopyroxene and c, d clinopyroxene. Plotted are minerals from natural samples COM-1 (white diamonds) and Ap-1 (grey diamonds), experiments (COM-1_37, 52, 55) used to delineate the Comal Chico MSP (red stars), sub-liquidus MSP experiments (yellow triangles, COM-48, COM-36), and ultramafic xenoliths (blue-rimmed circles and diamonds). Olivine-free xenoliths are from "La Olivina" E-type pyrox-

enites (Nimz et al. 1993); olivine-bearing xenoliths are from Santo Domingo, Ventura-Espíritu Santo, El Peñón and San Quintín (Luhr and Aranda-Gómez 1997; Blatter and Carmichael 1998; Housh et al. 2010). Only xenoliths from El Peñón (Blatter and Carmichael 1998) are directly related to the TMVB, the other xenoliths are from the surrounding extensional region 
different mineral assemblages. The $2 \mathrm{wt} \% \mathrm{H}_{2} \mathrm{O}$ diagram (Fig. 1Sa) reveals that olivine is a liquidus phase only at 1.6 $\mathrm{GPa}$. Clinopyroxene is the liquidus phase at $1.7-1.8 \mathrm{GPa}$, as orthopyroxene approaches the liquidus to supplant olivine as the second phase to appear. The $4 \mathrm{wt} \% \mathrm{H}_{2} \mathrm{O}$ content diagram (Fig. 1 $\mathrm{Sb}$ ) presents a closer approach to an MSP at $1.6 \mathrm{GPa}$ with olivine and clinopyroxene as liquidus phases closely followed by mica, although orthopyroxene is absent.

Our experimental results reproduce several features predicted by pMELTS modelling. The experimental MSP is found for COM- 1 with between 4 and $2 \mathrm{wt} \%$ of water content in the same range of pressure and temperature. The olivine stability field extents to higher pressure at decreasing water content, while, clinopyroxene and phlogopite (biotite in pMELTS) are liquidus phases only at water content over $3 \mathrm{wt} \%$. The agreement between pMELTS and experiments is encouraging and suggests that pMELTS can be used as a means to estimate multiple saturation conditions for K-rich basaltic magmas, where the hydrous mineral phase is mica. The extent to which pMELTS can be used to find MSP in more Na-rich systems when amphibole is the dominant hydrous phase, remains to be tested.

\section{Comparison with eruption temperatures}

Our results show that the high- $\mathrm{K}_{2} \mathrm{O}$ primitive basalts of Comal Chico are multiply-saturated with phlogopite + spinel + clinopyroxene + orthopyroxene + olivine at $1300 \pm 10{ }^{\circ} \mathrm{C}, 1.7 \pm 0.1 \mathrm{GPa}$ (Fig. 5). At these conditions, the $\mathrm{fO}_{2}$ and $\mathrm{H}_{2} \mathrm{O}$ contents of the melt are a close match to those estimated for Comal Chico and similar CVC basanites (Vigoroux et al. 2008; Carmichael et al. 2006). However, the MSP temperature is higher than the calculated eruption temperature (1060-1090 ${ }^{\circ} \mathrm{C}$, based on phlogopite geothermometry, Righter and Carmichael 1996). The difference of $210-240{ }^{\circ} \mathrm{C}$ is suggestive of near-adiabatic cooling during ascent (see Fig. 8). For hydrous basalts we can estimate the adiabat using the relationship (McKenzie and Bickle, 1988):

$\left(\frac{\partial T}{\partial z}\right)=\frac{g \alpha T}{C_{p}}$

where $T$ is the absolute temperature (in $\mathrm{K}$ ), $z$ is the depth, $\alpha$ is the thermal expansivity of the melt, $C_{p}$ is its heat capacity at constant pressure, and $g$ is the gravitational acceleration. We use the following experimentally-derived thermodynamic properties for hydrous basalt with $\sim 4 \mathrm{wt} \%$ dissolved $\mathrm{H}_{2} \mathrm{O}: \alpha=3.45 \times 10^{-5} \mathrm{~K}-1$ (Ochs and Lange 1999); $C_{p}=95.6 \mathrm{~J} / \mathrm{mol} / \mathrm{K}$ (Di Genova et al. 2014). At $1500 \mathrm{~K}$, the calculated adiabatic cooling is $5.3^{\circ} \mathrm{C} / \mathrm{km}$. For the ascent of $\sim 60 \mathrm{~km}$ from the MSP (1.7 GPa) to the surface, adiabatic cooling should be of the order $320^{\circ} \mathrm{C}$. This value is offset by latent heat release due to decompression crystallisation
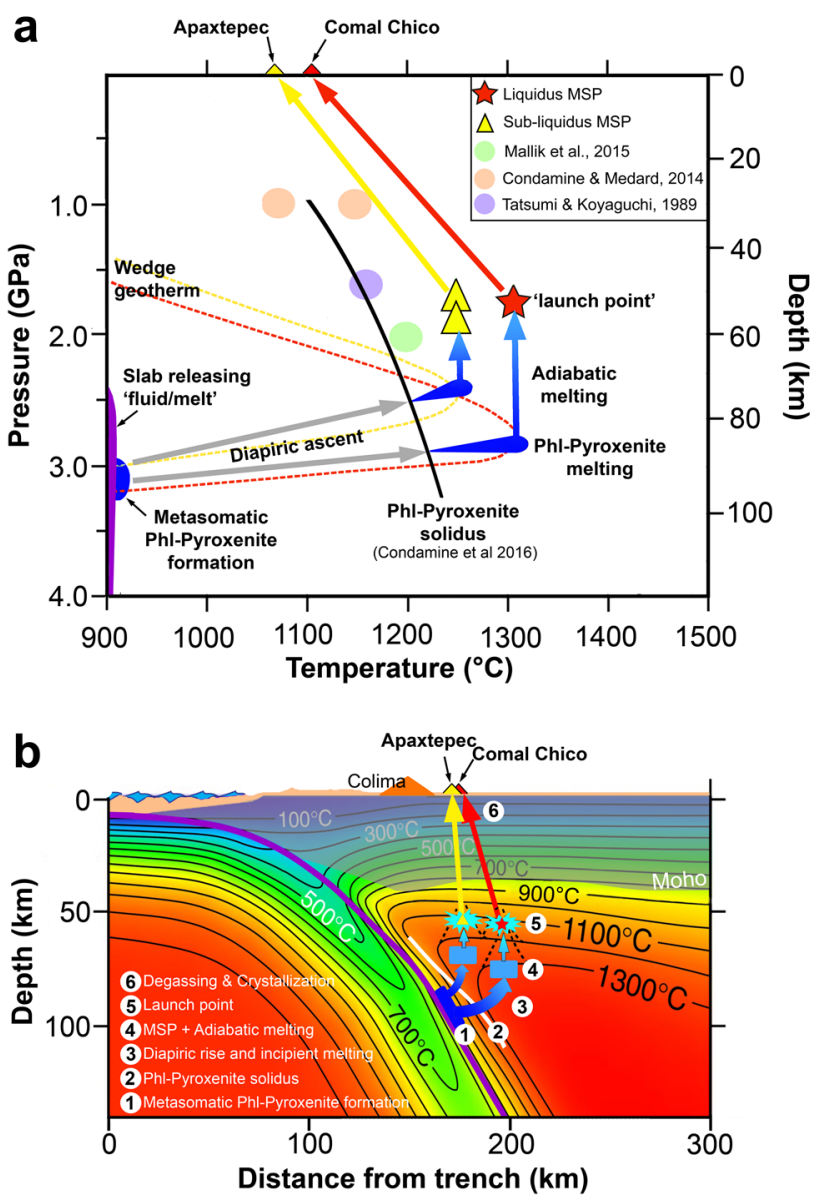

Fig. 8 Proposed melting regime beneath CVC. a P-T section with geotherms based on the thermal structure of Ferrari et al. (2012), also replicated in (b), and the three MSPs derived in this study. Red and yellow dashed lines denote the two ascent trajectories in $\mathbf{b}$ marked as ' 3 '. b The $2 \mathrm{D}$ static thermal model of the western TMVB as presented by Ferrari et al. (2012, section A-A') using the slab geometry of the MARS experiment (Yang et al. 2009) and the numerical procedure of Manea et al. (2004) for an isoviscous mantle wedge. The location of Colima, Comal Chico and Apaxtepec cones are indicated (not to scale). The slab-wedge interface is represented by a purple line in both panels. In $\mathbf{a}, \mathbf{b}$ we use coloured symbols and arrows to denote key stages in the generation of CVC primitive magmas (also numbered in (b)). The dark blue ovoid denotes metasomatism at the slab-wedge interface as slab-derived fluids react with mantle peridotite to produce phlogopite pyroxenite veins (Sekine and Wyllie 1983). Buoyant, ascent of veined mantle diapirs is shown by the arrows, grey in $\mathbf{a}$ and shaded to a lighter blue in $\mathbf{b}$, where the initial ascent is deflected to horizontal by the down-dragged mantle. Incipient melting in the diapirs starts as they cross the phlogopite pyroxenite dehydration solidus, taken from Condamine et al. (2016) and shown as a black line in $\mathbf{a}$ and a white line in $\mathbf{b}$. Subsequent decompression melting of veined mantle diapirs are shown by further lightening of the blue arrows, terminating at the launch points (MSPs) where melts segregate from their solid residues (red star for Comal Chico, yellow triangles for Apaxtepec). Subsequent, adiabatic ascent paths of segregated melts, corresponding to Comal Chico and Apaxtepec primitive compositions, are shown by the red and yellow arrows; these paths incorporate the combined effects adiabatic cooling and latent heat release, as described in the text. Decompression crystallisation takes place in the shallow crust (probably assisted by degassing) to produce the observed phenocryst assemblages. Pastel ellipses as in Fig. 6 
of phenocrysts, which is $\sim 3.7 \mathrm{~K}$ for each per cent crystallised (as calculated by pMELTS). Thus, for COM-1 cooling due to adiabatic ascent coupled with $\sim 20 \%$ decompression crystallisation should amount to $240{ }^{\circ} \mathrm{C}$, in good agreement with the observations presented above.

\section{Melting reactions in heterogeneous mantle wedge}

As previously shown, COM-1 is more consistent with the melting of phlogopite-pyroxenite that produces olivine as a peritectic product, rather than melting of phlogopite-lherzolite. The MSP temperature is consistent with the olivine-melt temperatures for COM-1 phenocrysts $\left(1280 \pm 20^{\circ} \mathrm{C}\right.$, olivine-liquid geothermometer of Putirka, 2008). Moreover, olivine at the MSP has the same compositions as the phenocryst cores for both major and minor components (Fig. 7). This similarity suggests that olivine, a melting reaction product, started to crystallise from the COM-1 melt at, or shortly after leaving, the MSP. Conversely, MSP clinopyroxene, a melting reaction reactant, is slightly more aluminous and sodic that in COM-1 $\left(\mathrm{Al}_{2} \mathrm{O}_{3}>3 \mathrm{wt} \%\right.$ and $\mathrm{Na}_{2} \mathrm{O}>0.5 \mathrm{wt} \%$; Fig. 6), which probably reflects crystallisation of clinopyroxene in COM-1 during ascent to lower pressures, rather than as a relic from the source region.

We have calculated the stoichiometry of the melting reaction by multiple regression of COM-1 against the mineral compositions for the experiments that delimited the liquidus MSP (COM-1_37, 52, and 55). We also calculated reactions for the two sub-liquidus MSP (COM-1_36, and 48). As the experimental spinel is $<1 \mu \mathrm{m}$ and cannot be analysed, spinel associated with natural olivines in COM-1 was used for calculations. Spinel usually occurs as inclusions in olivine in COM-1. The standard error is shown within the parentheses.

(1) Liquidus MSP of COM-1

$0.25(11)$ opx $+0.55(7) \mathrm{cpx}+0.48(7) \mathrm{phl}+0.02(2)$ $\mathrm{sp}=1.0 \mathrm{liq}+0.30(5) \mathrm{ol}$.

(2) Sub-liquidus MSP

(2a) COM_36; 0.46(17) opx +0.41(8) cpx + 0.58(10) $\mathrm{phl}+0.04(3) \mathrm{sp}=1.0 \mathrm{liq}+0.49(8) \mathrm{ol}$.

(2b) COM_48; 0.74(20) opx + 0.44(11) cpx + 0.44(12) $\mathrm{phl}+0.11(5) \mathrm{sp}=1.0$ liq $+0.73(10) \mathrm{ol}$.

Melting along with the peritectic proceeds until one of the reactant mineral phases is exhausted. The high coefficient for phlogopite in all reactions indicates that this phase is likely to be the first to be consumed during melting of phlogopite pyroxenite due to its lower initial source abundance than pyroxenes. Thus, we propose that generation of COM-1 proceeded by melting of phlogopite pyroxenite up to the point of phlogopite consumption, at which stage the melt segregated from its source and ascended to the surface; this point of segregation corresponds to the MSPs.
Mantle melting can be driven by heating or decompression or a combination of both if metasomatic lithologies, such as phlogopite pyroxenite, undergo ascent. Condamine et al. (2016) locate their phlogopite-pyroxenite solidus at temperatures ranging from $1100{ }^{\circ} \mathrm{C}$ at $1 \mathrm{GPa}$ to $1175{ }^{\circ} \mathrm{C}$ at $2 \mathrm{GPa}$, which is well below the peridotite solidus (see Fig. 8a). This is consistent with the solidus of phlogopite clinopyroxenite (i.e. opx-free) determined by Lloyd et al. (1985) at $2 \mathrm{GPa}$ and $\sim 1175^{\circ} \mathrm{C}$. In their experiments, where melting is also peritectic ( $\mathrm{phlog}+\mathrm{cpx}=$ olivine + melt $)$, phlogopite is exhausted by $1250{ }^{\circ} \mathrm{C}$ when the melt fraction is $\sim 0.6$. The starting material for their experiments contained $35 \%$ phlogopite, thus the melt fraction at phlogopite-out is broadly consistent with the reaction stoichiometry presented above, i.e. $48 \%$ of the melt is contributed by phlogopite. We attribute the higher temperature and lower pressure of our MSP to a slightly more refractory protolith. We propose that the source for COM-1 was a phlogopite-pyroxenite that underwent decompression melting to the point of phlogopite exhaustion. The onset of melting likely lay at higher pressures, but similar temperatures. It is not possible from the experiments alone to gauge the melt fraction at the point of segregation, other than to say it is equivalent to $48 \%$ of the original phlogopite mode, according to melting reactions (1 and 2).

Melting to the point of phlogopite-out is consistent with the $\mathrm{K}_{2} \mathrm{O}$ and $\mathrm{H}_{2} \mathrm{O}$ contents of COM-1. If, as is likely, phlogopite is the only source of these two components in the protolith and product olivine does not provide a sink for them, then $\mathrm{K}_{2} \mathrm{O}$ and $\mathrm{H}_{2} \mathrm{O}$ contents of primary melts will be equal to $48 \%$ of their concentration in phlogopite $\left(\sim 6 \mathrm{wt} \% \mathrm{H}_{2} \mathrm{O}\right.$ and $9 \mathrm{wt} \% \mathrm{~K}_{2} \mathrm{O}$ ). This equates to $\sim 3 \mathrm{wt} \% \mathrm{H}_{2} \mathrm{O}$ and $4.5 \mathrm{wt} \% \mathrm{~K}_{2} \mathrm{O}$, in broad agreement with the values for COM-1 and other CVC basanites. In other words, $\mathrm{K}_{2} \mathrm{O}$ and $\mathrm{H}_{2} \mathrm{O}$ contents of primary high-K melts are likely to be buffered by peritectic melting of phlogopite-bearing lithologies in the mantle, up to the point of phlogopite exhaustion, as previously proposed by Condamine and Médard (2014). At higher melt fractions $\mathrm{K}_{2} \mathrm{O}$ and $\mathrm{H}_{2} \mathrm{O}$ become progressively diluted in the melt.

At the point of segregation (or 'launch' in Fig. 8) from its source, COM-1 basanite ascended near-adiabatically. The subsequent crystallisation sequence tracks the lower pressure phase relations, which our experiments (Fig. 5) show to be olivine + spinel + clinopyroxene \pm phlogopite (depending on $\mathrm{H}_{2} \mathrm{O}$ content), consistent with phenocrysts in COM-1. The first phase to crystallise, olivine, has a core composition (and temperature) close to that of the MSP, indicating the onset of olivine crystallisation shortly after launch. Phlogopite, plagioclase and cpx, observed as COM-1 phenocrysts, crystallised at shallower levels in the crust, possibly due to degassing during ascent. 


\section{Melt evolution in the mantle wedge}

The determination of two additional MSPs below the liquidus of COM-1 (Fig. 5), but containing melts that match other cinder cone lavas from CVC (Fig. 6), raises the possibility that peritectic melting (reaction $2 b$ ) of phlogopite-bearing lithologies is an important process in controlling chemical diversity in primitive arc magmas. Chemical variation in cinder cone lavas from CVC is shown in Fig. 2. The spread of lava compositions from COM-1 to lower $\mathrm{MgO}$ cannot be readily generated by fractionation of olivine \pm clinopyroxene. For example, $\mathrm{K}_{2} \mathrm{O}$ contents remain flat or fall slightly with decreasing $\mathrm{MgO}$, requiring significant fractionation of a potassic phase, such as phlogopite, but in proportions ( $\sim 50 \%$ by weight) that are inconsistent with the observed phenocryst assemblage. The behaviour of $\mathrm{Al}_{2} \mathrm{O}_{3}$ and $\mathrm{TiO}_{2}$ is equally hard to reconcile with olivine + clinopyroxene crystallisation. Instead, the match of the two low-temperature MSP melts to the cinder cone compositional trend suggests that melt evolution occurring elsewhere in the mantle wedge beneath the CVC is controlled by similar peritectic reactions to that responsible for COM-1.

The two low-temperature MSPs (reaction 2a and 2b) are an excellent match to more evolved cinder cone lavas, with the exception of $\mathrm{Na}_{2} \mathrm{O}$ in COM-1_48 glass (Fig. 2). This is likely due to Na-loss during the analysis of this experiment (Table 2). The flat $\mathrm{K}_{2} \mathrm{O}$ trends in the cinder cone data are consistent with buffering by phlogopite, as described above. The slight fall in $\mathrm{K}_{2} \mathrm{O}$ below $8 \mathrm{wt} \% \mathrm{MgO}$ (as also evident in COM-1_48 glass) may reflect a decrease in the stoichiometric coefficient of phlogopite in the melting reaction at lower temperatures (cf. reactions 1 and 2). Alternatively, the $\mathrm{K}_{2} \mathrm{O}$ of the natural melts may have become diluted at higher degrees of melting beyond phlogopite-out prior to launching from their mantle source region.

\section{Mineral analogues with mantle lithologies}

Clinopyroxenes at the MSPs have compositions that are distinct from phenocryst clinopyroxene in COM-1 and Apaxtepec. However, both clinopyroxene and orthopyroxene at the MSPs are consistent with compositions found in mantle rocks (Falloon et al. 1999; Funk and Luth 2012) (Fig. 7). Xenolith pyroxene compositions come from lithologies that range from harzburgite (orthopyroxene) to fertile peridotite and pyroxenite (clinopyroxene). This diversity of xenolith lithology and mineral chemistry is further evidence of a heterogeneous mantle beneath the CVC. The scarcity of mantle xenoliths rich in phlogopite as inferred for the source of Comal Chico and other CVC basanites may reflect the fact that phlogopite was melted out of these rocks prior to (or during) their entrainment and transport to the surface. Natural samples and experiments have clearly demonstrated the potential of subduction zone metasomatism to produce amphibole- (e.g., Johnson et al. 1996; Niiada and Green 1999; Brooker et al. 2004) and/or phlogopite-bearing (Arai 1986; Ionov and Hofmann 1995) peridotite or sometimes more exotic ultramafic lithologies rich in phlogopite (Zanetti et al 1999; McInnes et al 2001). Such metasomatism is recorded in the Mexican mantle and is superimposed on any pre-existing heterogeneities, such as depleted harzburgite (NAY-harzburgite, Housh et al. 2010) refertilised peridotite (SLP-lherzolite; Luhr and Aranda-Gómez 1997, PeñonLherzolite; Blatter and Carmichael 1998) or pyroxenite (La Olivina, Nimz et al. 1993) as metasomatic fluids or melts percolate through the wedge. Of these, the Peñon example (Blatter and Carmichael 1998) is directly associated with the current TMVB; the others belong to provinces related to previous subduction events (Ferrari et al. 2012).

Metasomatism of the mantle wedge can occur directly above the subducting slab, as released hydrous fluids react with peridotite. Metasomatic lithologies may then ascend buoyantly into the mantle wedge, eventually undergoing melting through heating by the ambient mantle and/ or decompression ('hybridization' of Wyllie and Sekine 1982) once they encounter the phlogopite-pyroxenite solidus (Fig. 8). The experimental study of Sekine and Wyllie (1983) shows that reaction at $3 \mathrm{GPa}$ and $950{ }^{\circ} \mathrm{C}$ of mantle peridotite with hydrous granitic slab-derived fluids drives metasomatic reactions that consume olivine and produce phlogopite \pm garnet, resulting in phlogopite pyroxenites with or without garnet along the slab-wedge interface. Sekine and Wyllie (1983) suggest that metasomatic lithologies formed close to the slab interface then ascend buoyantly into the hotter mantle where they undergo partial melting. This interpretation is entirely consistent with our model in Fig. 8. Mallik et al. (2015) use the forward approach with subducted sediments + lherzholite producing melts in equilibrium with phlogopite + orthopyroxene + clinopyroxene (tr) + olivine (tr) at $2 \mathrm{GPa}, 1200{ }^{\circ} \mathrm{C}$ to establish a peritectic reaction stoichiometrically close to our reactions (a and 2). In Fig. 6 the MSP melt compositions from this study are compared with those captured by Mallik et al. (2015), Sekine and Wyllie (1983) and Condamine and Medard (2014) as well as Tatsumi and Koyaguchi (1989). The large uncertainties represented for the melt composition from Mallik et al. (2015) emphasise the difficulties inherent in the forward experimental approach, where melt fraction is inevitably very small. Figure 6 clearly demonstrates that peritectic reactions involving phlogopite, orthopyroxene, clinopyroxene and olivine can reproduce the chemical diversity present in the CVC. 


\section{Magma launch points and the thermal state of sub-arc mantle}

Our experimentally determined $\mathrm{P}-\mathrm{T}$ conditions at the COM-1 liquidus MSP place tight constraints on the thermal structure of the wedge, a parameter that is notoriously hard to establish using thermal models alone, because of uncertainty over the coupling depth of the subducting slab and the mantle wedge (Syracuse et al, 2010). The pressure of our liquidus MSP $(1.7 \pm 0.1 \mathrm{GPa})$ corresponds to a depth of $59 \pm 3 \mathrm{~km}$, calculated assuming a crust density of $2850 \mathrm{~kg}$ $\mathrm{m}^{3}$ (Urrutia-Fucugauchi and Molina-Garza 1992), mantle density of $3250 \mathrm{~kg} \mathrm{~m}^{-3}$ and Moho at $40 \mathrm{~km}$. Thus, the temperature is $1300{ }^{\circ} \mathrm{C}$ at $59 \mathrm{~km}$ depth beneath CVC; the exact horizontal co-ordinate depends on the ascent path taken by the magma. In Fig. 8 this P-T point is overlain onto one of the mantle wedge thermal models available for this area (Ferrari et al. 2012). The MSP lies at temperatures some $200{ }^{\circ} \mathrm{C}$ hotter than the model, which may reflect the difficulty of thermal modelling in this tectonically complex region. Alternatively, as these are static thermal models, the discrepancy may testify to significant advective heat flux as parcels of mantle, in this case phlogopite-pyroxenite, ascend from deeper in the wedge (dashed isotherms in Fig. 8b). This interpretation is consistent with decompression melting of the source during ascent, perhaps facilitated by rifting of the overlying CVC. If the solidus of phlogopite-pyroxenite is consistent with experimental determinations in the synthetic system (Condamine et al. 2016), then a parcel of $1300{ }^{\circ} \mathrm{C}$ phlogopite pyroxenite-bearing, metasomatised mantle will start to melt in the hot core of the mantle wedge at pressures of around $2.5 \mathrm{GPa}(83 \mathrm{~km}$; Fig. 8). As it ascends further it will continue to melt, due to the positive Clapeyron slope of the solidus. Beneath the CVC this decompression melting stops at $59 \mathrm{~km}$ when the basanite melt segregates from its source and launches upwards. We suggest, on the basis of the $\mathrm{K}_{2} \mathrm{O}$ and $\mathrm{H}_{2} \mathrm{O}$ contents of $\mathrm{CVC}$ basanites, that this launch point is controlled by the exhaustion of phlogopite in the source, although we cannot rule out mechanical explanations for melt segregation at this depth.

The two sub-liquidus MSPs also lie at temperatures above the calculated geotherms This may reflect continued re-equilibration and melting of the mantle along the peritectic to lower temperatures, or ascent of cooler parts of the mantle wedge containing phlogopite pyroxenite, in either case producing more evolved (lower $\mathrm{MgO}$ ) CVC cinder cone magmas. This interpretation suggests that decompression melting of phlogopite-bearing, sub-arc mantle, driven by rifting of the Colima Graben, is an important process in generating primitive melts. Additionally, the ubiquity of high-K silicaundersaturated magmas along the TMVB (Gómez-Tuena et al. 2018) can also be products of similar metasomatic pyroxenite melting. The olivine chemistry presented for the central TMVB (Straub et al. 2008) and other arcs in the world with high-K series magmas (Nikogosian and Bergen 2010; Foley et al. 2013) also testifies to the potential influence of an olivine-free source. Therefore, our experiments reinforce the possibility that these kinds of magmas derive from lithologies other than simple lherzolitic or harzburgitic peridotites.

\section{Conclusions}

High-potassium, primitive CVC magmas have been shown experimentally to form by peritectic melting of phlogopitepyroxenite lithologies at depths of $\geq 59 \mathrm{~km}$. These source lithologies are likely to occur as parcels of buoyant, oxidised, metasomatised wedge material formed close to the slab interface ascend into the hot core of the wedge, crossing their solidus around $83 \mathrm{~km}$ depth. During the further ascent, melting proceeds to the point of phlogopite exhaustion, which serves to buffer the $\mathrm{K}_{2} \mathrm{O}$ and $\mathrm{H}_{2} \mathrm{O}$ of CVC basanites. The point of last equilibrium with the source, marks the onset of segregation and detachment (or launch) of the melts and near-adiabatic magma ascent to the surface, with little subsequent chemical modification, thereby preserving their primitive nature upon eruption. The discovery of two further MSPs delineates the continuation of the peritectic to lower temperatures. Melts lying along with this peritectic match other primitive magmas from the CVC, suggesting that this reaction boundary exercises a strong control on magma chemistry in the mantle wedge. This provides a mechanism for generating primitive magma diversity in arcs that are undergoing extension, as diverse, metasomatised mantle lithologies decompress and begin to melt. We propose that buoyant ascent of metasomatised lithologies, perhaps as diapirs or plumes (Gerya et al. 2006), is a fundamental process of primary arc magma generation. That is especially evident in rifted arc segments where mantle wedge decompression and magma ascent are facilitated. Our results demonstrate that the inverse experimental approach is a valuable tool to explore mantle wedge thermal structure over a range of P-T- $\mathrm{H}_{2} \mathrm{O}-\mathrm{fO}_{2}$, providing that sufficient experiments are performed to fully define the liquidus saturation surface in the case of peritectic melting.

Acknowledgements This work was supported by Natural Environment Council grants NE/N001966/1, IMF668/1118 and CONACyT Scholarship (Becerra-Torres). We are thankful for analytical assistance of C.-J. De Hoog (NERC Ion Micro-probe Facilities, University of Edinburgh), S. Kearns and B. Buse (Electron Microprobe Facilities, University of Bristol) and Martin Mangler for providing samples. The manuscript has greatly benefited from insightful comments by D. Blatter and an anonymous reviewer, and by the editor, T. Grove.

Open Access This article is licensed under a Creative Commons Attribution 4.0 International License, which permits use, sharing, 
adaptation, distribution and reproduction in any medium or format, as long as you give appropriate credit to the original author(s) and the source, provide a link to the Creative Commons licence, and indicate if changes were made. The images or other third party material in this article are included in the article's Creative Commons licence, unless indicated otherwise in a credit line to the material. If material is not included in the article's Creative Commons licence and your intended use is not permitted by statutory regulation or exceeds the permitted use, you will need to obtain permission directly from the copyright holder. To view a copy of this licence, visit http://creativecommons .org/licenses/by/4.0/.

\section{References}

Allan JF, Carmichael ISE (1984) Lamprophyric lavas in the Colima graben, SW Mexico. Contrib Mineral Petrol 88:203-216. https:// doi.org/10.1007/BF00380166

Arai S (1986) K/NA variation in phlogopite and amphibole of upper mantle peridotites due to fractionation of the metasomatizing fluids. Jour Geol 94:436-444

Asimow PD, Longhi J (2004) The significance of multiple saturation points in the context of polybaric near-fractional melting. J Petrol 45:2349-2367. https://doi.org/10.1093/petrology/egh043

Ballhaus C, Berry RF, Green DH (1991) High pressure experimental calibration of the olivine-orthopyroxene-spinel oxygen geobarometer: implications for the oxidation state of the upper mantle. Contrib Mineral Petrol 107:27-40. https://doi.org/10.1007/BF003 11183

Blatter DL, Carmichael ISE (1998) Horblende peridotite xenoliths from central Mexico reveal the highly oxidised nature of the subarc upper mantle. Geology 26:1015-1038. https://doi. org/10.1130/0091-7613(1998)026<1035:HPXFCM > 2.3.CO;2

Borisov A, Behrens H, Holtz F (2015) Effects of melt composition on $\mathrm{Fe} 3+/ \mathrm{Fe} 2+$ in silicate melts: a step to model ferric/ferrous ratio in multicomponent systems. Contrib Mineral Petrol 169:24. https://doi.org/10.1007/s00410-015-1119-6

Bouilhol P, Burg JP, Bodinier JL et al (2009) Magma and fluid percolation in arc to forearc mantle: evidence from Sapat (Kohistan, Northern Pakistan). Lithos 107:17-37. https://doi.org/10.1016/j. lithos.2008.07.004

Brooker R, Holloway JR, Hervig RL (1998) Reduction in piston cylinder experiments: the detection of carbon infiltration into platinum capsules. Amer Mineral 83:985-994

Brooker RA, James RH, Blundy JD (2004) Trace elements and $\mathrm{Li}$ isotope systematics in Zabargad peridotites; evidence of ancient subduction processes in the Red Sea mantle. Chem Geol 212:179-204

Burnham CW (1979) The importance of volatile constituents. In: Yoder HS (ed) The evolution of the igneous rocks; 50th anniversary perspective. Princeton University Press, Princeton, pp 439-482

Carmichael ISE, Frey HM, Lange RA, Hall CM (2006) The Pleistocene cinder cones surrounding Volcán Colima, Mexico revisited: Eruption ages and volumes, oxidation states, and sulfur content. Bull Volcanol 68:407-419. https://doi.org/10.1007/s0044 5-005-0015-8

Conceiçao RV, Green DH (2004) Derivation of potassic (shoshonitic) magmas by decompression melting of phlogopite+pargasite lherzolite. Lithos 72:209-229. https://doi.org/10.1016/j.litho s.2003.09.003

Condamine P, Médard E (2014) Experimental melting of phlogopitebearing mantle at $1 \mathrm{GPa}$ : implications for potassic magmatism. Earth Planet Sci Lett 397:80-92. https://doi.org/10.1016/j. eps1.2014.04.027
Condamine P, Médard E, Devidal JL (2016) Experimental melting of phlogopite-peridotite in the garnet stability field. Contrib Mineral Petrol 171:1-26. https://doi.org/10.1007/s00410-016-1306-0

Di Genova D, Romano C, Giordano D, Alletti M (2014) Heat capacity, configurational heat capacity and fragility of hydrous magmas. Geochim Cosmochim Acta 142:314-333. https://doi. org/10.1016/j.gca.2014.07.012

Edgar AD, Charbonneau HE, Mitchell RH (1992) Phase relations of an armalcolite-phlogopite lamproite from smoky butte, Montana: applications to lamproite genesis. J Petrol 33:505-520. https://doi. org/10.1093/petrology/33.3.505

Elkins-Tanton LT, Grove TL (2003) Evidence for deep melting of hydrous metasomatized mantle: pliocene high-potassium magmas from the Sierra Nevadas. J Geophys Res Solid Earth 108(B7):2350. https://doi.org/10.1029/2002JB002168

Falloon TJ, Green DH, Jacques AL, Hawkins JW (1999) Refractory magmas in back-arc basin settings-experimental constraints on the petrogenesis of a Lau Basin example. J Petrol 40:255-277. https ://doi.org/10.1093/petroj/40.2.255

Ferrari L, Orozco-Esquivel T, Manea V, Manea M (2012) The dynamic history of the trans-mexican volcanic belt and the mexico subduction zone. Tectonophysics 522-523:122-149. https://doi. org/10.1016/j.tecto.2011.09.018

Foley SF, Prelevic D, Rehfeldt T, Jacob DE (2013) Minor and trace elements in olivines as probes into early igneous and mantle melting processes. Earth Planet Sci Lett 363:181-191. https:// doi.org/10.1016/j.epsl.2012.11.025

Funk SP, Luth RW (2012) An experimental study of a minette from the milk river area, southern Alberta, Canada. Contrib Mineral Petrol 164:999-1009. https://doi.org/10.1007/s00410-012-0785-x

Gaetani GA, Grove TL (2003) Experimental constraints on melt generation in the mantle wedge. Washingt DC Am Geophys Union Geophys Monogr Ser 138:107-134. https://doi.org/10.1029/138GM07

Gertisser R, Self S, Thomas LE, Handley HK, Van Calstern P, Wolff JA (2012) Processes and timescales of magma genesis and differentiation leading to the great Tambora eruption in 1815. J Pertol 53:271-297

Gerya TV, Connolly JAD, Yuen DA et al (2006) Seismic implications of mantle wedge plumes. Phys Earth Planet Inter 156:59-74. https ://doi.org/10.1016/j.pepi.2006.02.005

Ghiorso MS, Hirschmann MM, Reiners PW, Kress VC (2002) The pMELTS: A revision of MELTS for improved calculation of phase relations and major element partitioning related to partial melting of the mantle to $3 \mathrm{GPa}$. Geochemistry Geophys Geosystems 3:36. https://doi.org/10.1029/2001gc000217

Gómez-Tuena A, Mori L, Goldstein SL, Pérez-Arvizu O (2011) Magmatic diversity of western Mexico as a function of metamorphic transformations in the subducted oceanic plate. Geochim Cosmochim Acta 75:213-241. https://doi.org/10.1016/j.gca.2010.09.029

Gómez-Tuena A, Mori L, Straub SM (2018) Geochemical and petrological insights into the tectonic origin of the transmexican volcanic belt. Earth Sci Rev 183:153-181. https://doi.org/10.1016/j. earscirev.2016.12.006

Grant TB, Harlov DE, Rhede D (2016) Special collection: new advances in subduction zone magma genesis: Experimental formation of pyroxenite veins by reactions between olivine and $\mathrm{Si}$, $\mathrm{Al}, \mathrm{Ca}, \mathrm{Na}$, and $\mathrm{Cl}$-rich fluids at $800^{\circ} \mathrm{C}$ and $800 \mathrm{MPa}$ : Implications for fluid metasomatism in the mantle wedge. Am Mineral 101:808-818. https://doi.org/10.2138/am-2016-5441

Green DH, Ringwood AE (1967) The genesis of basaltic magmas. Contrib Mineral Petrol 15:103-190. https://doi.org/10.1007/ BF00372052

Grove TL, Till CB (2019) H2O-rich mantle melting near the slabwedge interface. Contrib Mineral Petrol 174:1-22. https://doi. org/10.1007/s00410-019-1615-1 
Grove TL, Elkins-Tanton LT, Parman SW et al (2003) Fractional crystallization and mantle-melting controls on calc-alkaline differentiation trends. Contrib Mineral Petrol 145:515-533. https://doi. org/10.1007/s00410-003-0448-Z

Hall LJ, Brodie J, Wood BJ, Carroll MR (2004) Iron and water losses from hydrous basalts contained in Au $80 \mathrm{Pd} 20$ capsules at high pressure and temperature. Mineral Mag 68:75-81. https://doi. org/10.1180/0026461046810172

Hasenaka T, Carmichael ISE (1987) The cinder cones of michoacánguanajuato, central Mexico: petrology and chemistry. J Petrol 28:241-269. https://doi.org/10.1093/petrology/28.2.241

Hastie AR, Mitchell SF, Kerr AC et al (2011) Geochemistry of rare high-Nb basalt lavas: are they derived from a mantle wedge metasomatised by slab melts? Geochim Cosmochim Acta 75:50495072. https://doi.org/10.1016/j.gca.2011.06.018

Housh TB, Aranda-Gómez JJ, Luhr JF (2010) Isla Isabel (Nayarit, México): quaternary alkalic basalts with mantle xenoliths erupted in the mouth of the Gulf of California. J Volcanol Geotherm Res 197:85-107. https://doi.org/10.1016/j.jvolgeores.2009.06.011

Ionov DA, Hofmann AW (1995) Nb-Ta-rich mantle amphiboles and micas: implications for subduction-related metasomatic trace element fractionations. Earth Planet Sci Lett 131:341-356

Ishizuka O, Yuasa M, Tamura Y et al (2010) Migrating shoshonitic magmatism tracks Izu-Bonin-Mariana intra-oceanic arc rift propagation. Earth Planet Sci Lett 294:111-122. https://doi. org/10.1016/j.eps1.2010.03.016

Johnson KE, Davis AM, Bryndzia LT (1996) Contrasting styles of hydrous metasomatism in the upper mantle: an ion probe investigation. Geochim Cosmochim Acta 60:1367-1385

Kagi R, Müntener O, Ulmer P, Ottolini L (2005) Piston-cylinder experiments on $\mathrm{H} 2 \mathrm{O}$ undersaturated Fe-bearing systems: an experimental setup approaching fO2 conditions of natural calc-alkaline magmas. Am Mineral 90:708-717. https://doi.org/10.2138/ am.2005.1663

Katz RF, Spiegelman M, Langmuir CH (2003) A new parameterization of hydrous mantle melting. Geochemist Geophys Geosystems 4:9. https://doi.org/10.1029/2002GC000433

Kress VC, Carmichael ISE (1991) The compressibility of silicate liquids containing $\mathrm{Fe} 2 \mathrm{O} 3$ and the effect of composition, temperature, oxygen fugacity and pressure on their redox states. Contrib to Mineral Petrol 108:82-92. https://doi.org/10.1007/ BF00307328

Lloyd FE, Arima M, Edgar AD (1985) Partial melting of a phlogopite-clinopyroxenite nodule from south-west Uganda: an experimental study bearing on the origin of highly potassic continental rift volcanics. Contrib to Mineral Petrol 91:321-329. https://doi. org/10.1007/BF00374688

Luhr JF, Aranda-Gómez JJ (1997) Mexican peridotite xenoliths and tectonic terranes: correlations among vent location, texture, temperature, pressure, and oxygen fugacity. J Petrol 38:1075-1112. https://doi.org/10.1093/petroj/38.8.1075

Luhr JF, Carmichael ISE (1981) The colima volcanic complex, Mexico: part II. Late-quaternary cinder cones. Contrib Mineral Petrol 372:343-372

Mallik A, Nelson J, Dasgupta R (2015) Partial melting of fertile peridotite fluxed by hydrous rhyolitic melt at 2-3 GPa: implications for mantle wedge hybridization by sediment melt and generation of ultrapotassic magmas in convergent margins. Contrib Mineral Petrol 169:48. https://doi.org/10.1007/s00410-015-1139-2

Manea VC, Manea M, Kostoglodov V et al (2004) Thermal structure, coupling and metamorphism in the Mexican subduction zone beneath Guerrero. Geophys J Int 158:775-784. https://doi. org/10.1111/j.1365-246X.2004.02325.x

Manea VC, Manea M, Ferrari L (2013) A geodynamical perspective on the subduction of cocos and rivera plates beneath Mexico and central America. Tectonophysics 609:56-81. https://doi. org/10.1016/j.tecto.2012.12.039

Matjuschkin V, Brooker RA, Tattitch B, Blundy JD, Stamper CC (2015) Control and monitoring of oxygen fugacity in piston cylinder experiments. Contrib Mineral Petrol 169:9

McDade P, Wood BJ, Van Westrenen W et al (2002) Pressure corrections for a selection of piston-cylinder cell assemblies. Mineral Mag 66:1021-1028. https://doi.org/10.1180/0026461026660074

McInnes BIA, Gregoire M, Binns RA, Herzig PM, Hannington MD (2001) Hydrous metasomatism of oceanic sub-arc mantle, Lihir, Papua New Guinea: petrology and geochemistry of fluid-metasomatised mantle xenoliths. Earth Planet Sci Lett 188:169-183

McKenzie D, Bickle M (1988) The volume of melt generated by extension of the lithosphere. J Petrol 29:625-679

Médard E, Grove TL (2008) The effect of $\mathrm{H} 2 \mathrm{O}$ on the olivine liquidus of basaltic melts: experiments and thermodynamic models. Contrib Mineral Petrol 155:417-432. https://doi.org/10.1007/s0041 0-007-0250-4

Melekhova E, Blundy J, Robertson R, Humphreys MCS (2015) Experimental evidence for polybaric differentiation of primitive arc basalt beneath St. Vincent. Lesser Antilles J Petrol 56:161-192. https://doi.org/10.1093/petrology/egu074

Melzer S, Foley SF (2000) Phase relations and fractionation sequences in potassic magma series. Contrib Mineral Petrol 138:186-197

Mengel K, Green DH (1986) Experimental study of amphibole and phlogopite stability in metasomatized peridotite under watersaturated and water-undersaturated conditions. In: International kimberlite conference: extended abstracts, vol 4

Modreski PJ, Boettcher AL (1973) Phase relationships of Phl in the system $\mathrm{K} 2 \mathrm{O}-\mathrm{MgO}-\mathrm{CaO}-\mathrm{A} 12 \mathrm{O} 3-\mathrm{H} 2 \mathrm{O}$ to $35 \mathrm{kbar}$.pdf. Am J Sci 273:385-414

Nandedkar RH, Ulmer P, Müntener O (2014) Fractional crystallization of primitive, hydrous arc magmas: an experimental study at 0.7 GPa. Contrib Mineral Petrol 167:1-27. https://doi.org/10.1007/ s00410-014-1015-5

Niida K, Green DH (1999) Stability and chemical composition of pargasitic amphibole in MORB pyrolite under upper mantle conditions. Contrib Mineral Petrol 135:18-40

Nikogosian IK, van Bergen MJ (2010) Heterogeneous mantle sources of potassium-rich magmas in central-southern Italy: melt inclusion evidence from roccamonfina and ernici (Mid Latina Valley). J Volcanol Geotherm Res 197:279-302. https://doi.org/10.1016/j. jvolgeores.2010.06.014

Nimz GJ, Cameron KL, Niemeyer S (1993) The la olivina pyroxenite suite and the isotopic compositions of mantle basalts parental to the mid-cenozoic arc volcanism of northern mexico. J Geophys Res 98:6489-6509

O’Neill HSC, Pownceby MI (1993) Thermodynamic data from redox reactions at high temperatures. I. An experimental and theoretical assessment of the electrochemical method using stabilized zirconia electrolytes, with revised values for the $\mathrm{Fe}-\mathrm{FeO}$ ", $\mathrm{Co}-\mathrm{CoO}$, $\mathrm{Ni}-\mathrm{NiO}$ and $\mathrm{Cu}-\mathrm{Cu} 2 \mathrm{O}$ oxygen buf. Contrib to Mineral Petrol 114:296-314. https://doi.org/10.1007/BF01046533

Ochs FA, Lange RA (1999) The density of hydrous magmatic liquids. Science 80-(283):1314-1317. https://doi.org/10.1126/scien ce.283.5406.1314

Pichavant M, Mysen BO, Macdonald R (2002) Source and H2O content of high- $\mathrm{MgO}$ magmas in island arc settings: an experimental study of a primitive calc-alkaline basalt from St. Vincent. Lesser Antilles Arc Geochim Cosmochim Acta 66:2193-2209. https:// doi.org/10.1016/S0016-7037(01)00891-2

Portnyagin M, Bindeman I, Hoernle K, Hauff F (2007) Geochemistry of primitive lavas of the central kamchatka depression: magma generation at the edge of the pacific plate. Volcan Subduct Kamchatka Reg. https://doi.org/10.1029/172GM16 
Prouteau G, Scaillet B, Pichavant M, Maury R (2001) Evidence for mantle metasomatism by hydrous silicic melts derived from subducted oceanic crust. Nature 410:197-200. https://doi. org $/ 10.1038 / 35065583$

Putirka KD (2008) Thermometers and barometers for volcanic systems. Rev Mineral Geochemist 69:61-120. https://doi.org/10.2138/ rmg.2008.69.3

Righter K, Carmichael ISE (1996) Phase equilibria of phlogopite lamprophyres from western Mexico: biotite-liquid equilibria and $\mathrm{P}$ - T estimates for biotite-bearing igneous rocks. Contrib Mineral Petrol 123:1-21. https://doi.org/10.1007/s004100050140

Robin C, Mossand P, Camus G et al (1987) Eruptive history of the Colima volcanic complex (Mexico). J Volcanol Geotherm Res 31:99-113. https://doi.org/10.1016/0377-0273(87)90008-4

Rüpke LH, Morgan JP, Hort M, Connolly JAD (2004) Serpentine and the subduction zone water cycle. Earth Planet Sci Lett 223:17-34. https://doi.org/10.1016/j.epsl.2004.04.018

Schiano P, Clocchiatti R, Ottolini L, Sbrana A (2004) The relationship between potassic, calc-alkaline and Na-alkaline magmatism in South Italy volcanoes: a melt inclusion approach. Earth Planet Sci Lett 220:121-137. https://doi.org/10.1016/S0012-821X(04)00048 $-2$

Sekine T, Wyllie PJ (1983) Experimental simultaion of mantle hybridization in subduction zones. J Geol 91:511-528

Shishkina TA, Botcharnikov RE, Holtz F et al (2010) Solubility of $\mathrm{H} 2 \mathrm{O}$ - and $\mathrm{CO} 2$-bearing fluids in tholeiitic basalts at pressures up to 500MPa. Chem Geol 277:115-125. https://doi.org/10.1016/j. chemgeo.2010.07.014

Stamper CC, Melekhova E, Blundy JD, Arculus RJ, Humphreys MCS, Brooker RA (2014) Oxidised phase relations of a primitive basalt from Grenada. Lesser Antilles Contrib Mineral Petrol 167:954

Straub SM, LaGatta AB, Martin-Del Pozzo AL, Langmuir CH (2008) Evidence from high-Ni olivines for a hybridized peridotite/pyroxenite source for orogenic andesites from the central mexican volcanic belt. Geochemist Geophys Geosystems 9:3. https://doi. org/10.1029/2007GC001583

Syracuse EM, van Keken PE, Abers GA et al (2010) The global range of subduction zone thermal models. Phys Earth Planet Inter 183:73-90. https://doi.org/10.1016/j.pepi.2010.02.004

Tatsumi Y, Koyaguchi T (1989) An absarokite from a phlogopite lherzolite source. Contrib Mineral Petrol 102:34-40. https://doi. org/10.1007/BF01160189

Thomas RB, Hirschmann MM, Cheng H et al (2002) (231Pa/235U)$(230 \mathrm{Th} / 238 \mathrm{U})$ of young mafic volcanic rocks from nicaragua and costa rica and the influence of flux melting on U- series systematics of arc lavas. Geochim Cosmochim Acta 66:4287-4309. https ://doi.org/10.1016/S0016-7037(02)00993-6

Toplis MJ (2005) The thermodynamics of iron and magnesium partitioning between olivine and liquid: criteria for assessing and predicting equilibrium in natural and experimental systems. Contrib Mineral Petrol 149:22-39

Ulmer P (1989) The dependence of the Fe2+-Mg cation-partitioning between olivine and basaltic liquid on pressure, temperature and composition: an experimental study to $30 \mathrm{kbars}$. Contrib Mineral Petrol 101:261-273. https://doi.org/10.1007/BF00375311

Urrutia-Fucugauchi J, Molina-Garza RS (1992) Gravity modelling of regional crust and upper mantle structurre of the guerrero terrance-1. colima graben and southern sierra madre occidental, western mexico. Geofis Int 31:493-507

Vigouroux N, Wallace PJ, Kent AJR (2008) Volatiles in high-K magmas from the western trans-mexicanvolcanic belt : evidence for fluid fluxing and extreme enrichment of the mantle wedge by subduction processes. J Petrol 49:1589-1618. https://doi.org/10.1093/ petrology/egn039

Vollmer R, Norry MJ (1983) Possible origin of K-rich volcanic rocks from virunga, east Africa, by metasomatism of continental crustal material: $\mathrm{Pb}, \mathrm{Nd}$ and $\mathrm{Sr}$ isotopic evidence. Earth Planet Sci Lett 64:374-386. https://doi.org/10.1016/0012-821X(83)90097-3

Wyllie PJ (1984) Constraints imposed by experimental petrology on possible and impossible magma sources and products. Phil Trans R Soc Lond A 310:439-456

Wyllie PJ, Sekine T (1982) The formation of mantle phlogopite in subductions zone hybridization. Contrib Mineral Petrol 79:375-380

Yang T, Grand SP, Wilson D et al (2009) Seismic structure beneath the rivera subduction zone from finite-frequency seismic tomography. J Geophys Res 114:1-12. https://doi.org/10.1029/2008JB005830

Zanetti A, Mazzucchelli M, Rivalenti G, Vannucci R (1999) The Finero phlogopite-peridotite massif; an example of subduction-related metasomatism. Contrib Mineral Petrol 134:107-122

Publisher's Note Springer Nature remains neutral with regard to jurisdictional claims in published maps and institutional affiliations. 